\title{
CHILDRENS' POLITICAL ANECDOTES - REGISTER
}

\section{$\underline{\text { Kadi Sarv }}$}

In this article I intend to give an overview of Estonian schoolchildren's political anecdotes and conundrums. My source material is taken from the 1992 school traditions competition (Sarv 1997). I have compiled a list of anecdotes, for which the competition material was also used. In compiling the list, Marjut Kivelä's "Koululaishuumorin tyypiloettelo" has been used as a model.

All anecdotes containing political material are discussed, whether they involve individuals, ethnic groups or animals.

Political anecdotes and conundrums can be divided into three groups:

1. Anecdotes and conundrums about statesmen. Typical subjects are a visit, competition or outdoing each other;

2. Anecdotes which poke fun at the socialist or communist system, but in which specific statesmen are not mentioned;

3. Anecdotes about conditions of life, in which situations created by the crumbling system are described.

Political material can also be found in some animal anecdotes, three-nation anecdotes and in the modification of common abbreviations. In other genres such as song parodies, rebuses, etc., one can also detect a political background, although those genres will not be dealt with in this article.

Seppo Knuuttila argues that the whispered anecdote is a familiar term in some countries where freedom of speech is limited, and that the anecdote cannot be destroyed, although its voice can be stifled.

Alan Dundes conjectures that in the United States, due to the existence of the free press, political anecdotes (apart from brutal, sexual or racist anecdotes) are not part of oral culture.

The political anecdote, above all, is a popular rather than scholarly term.

The political anecdote is, consequently, a forbidden story which one can be punished for telling, and therefore told only to those one can trust, those who hold the same opinions as the anecdote-teller.

For that reason S. Knuuttila's term whispered anecdote is an excellent characterisation of the political anecdote. The phenomenon of the whispered anecdote characterises, above all, a repressive society in whpol people lack the opportunity to express their dissatisfaction legally.

The conundrum, a subcategory of the riddle, is widespread among children. These are usually spoken, although some are also written down in versebooks containing sayings and phrases which have appealed to the child, or in "oracle-versebooks" containing predictions about love and life. Apart from predictions and sentimental love stories, almost every versebook submitted to the school traditions competition also contained numerous conundrums. While occasionally it seemed that, due to copying from one versebook to an other, the conundrums contained were quite monotonous, this copying has played a significant role in the dissemination of the conundrums. 
An old-fashioned anecdote, the longer style of delivery of which has been forgotten over time, may sometimes take on the form of a conundrum. The so-called introduction falls away and the colourful punch line of the anecdote is used in the new conundrum. Political matter is just as often found in conundrums as in anecdotes. For some subjects, it even seems that the conundrum expresses attitudes and opinions more colourfully and precisely than the anecdote.

The heyday of the political anecdote was during the 1960s and 1970s. In arguing this, one must rely for the most part on personal impressions, since collecting political anecdotes for the archives was in the Soviet period dangerous (especially for the anecdote-teller), and therefore limited. The Krushchev "thaw" of the 1960's gave people back the courage to express their thoughts. During Stalin's rule, the spreading of such stories could have led to deportation to Siberia. The eighteenyear rule of Brezhnev can be seen as representing the evolution of the Soviet society towards absurdity. At the beginning of the 1960s, power was gentle and did not strike fear in to people, but towards the late $1970 \mathrm{~s}$, it became more aggressive.

During Gorbachev's "perestroika" the situation became more free, but this did not lead to a new flourishing of the political anecdote, since one was then able to put one's thoughts and ideas into practice through actual participation in politics.

\section{STATESMEN}

Within the category of anecdotes about statesmen, one can find anecdotes which, as opposed to those with true political content, would not be political if one was to remove the name of the main character. These are simply anecdotes which poke fun at human weakness, stupidity and evil behaviour. Only due to connection with the main character's person can these anecdotes be called political anecdotes.

The subjects of political anecdotes are transferred from one statesman to another. A story about one politician may over time begin to be told about another politician, depending on who is topical at the moment. According to Leea Virtanen, the same phenomenon can be seen in folk traditions, where motifs from many different sources accumulate around a favourite figure. For that reason stories told about previous statesmen collect around the name and person of later famous statesmen.

Some subjects are firmly attached to one particular politician. The reason for such a firm connection may be, among other things, that the story pokes fun at some special idiosyncrasy of the given statesman, which other politicians lack.

\section{Russians}

Vladimir Lenin. Forty-four anecdotes are connected with Lenin's name. Lenin may appear in anecdotes together with Gorbachev, Stalin and Brezhnev. Lenin appears in 20 conundrums. Lenin's name has also been used in a few fairly widespread conundrums, which had originally been connected with other statesmen. As regards the adaptation of abbreviations, Lenin's name is found in only one, that being for the abbreviation $N L K P$ [Estonian abbreviation for Communist Party of the Soviet Union - translator]. There are 74 copies of this abbreviation.

Joseph Stalin's name appears in 40 anecdotes. He often acts together with Lenin in stories in which there is no political material. He also often replaces a number of statesmen in more widespread anecdotes. Among conundrums, those connected with Stalin are few in number. His name appears in only five conundrums, and there is in most cases only one copy of each of these. Stalin is, however, often used in adaptations of the abbreviation SSSR [note: USSR in Russian - translator]. 
Nikita Krushchev only a couple of copies of each of the 11 anecdotes in which Krushchev appears. These are mostly connected with his glaring personality. In conundrums, also, most attention is given to Krushchev's appearance and his "achievements" in agriculture. Three of the six conundrums describe his appearance and two are about virgin land and maize cultivation.

Leonid Brezhnev is spoken of in 68 anecdotes. Half of these are connected with him alone. Neither Lenin, Stalin or even Gorbachev are so firmly linked to such specific anecdotes. Often Brezhnev also appears in anecdotes simply in his capacity as Soviet leader, and within that category of joke he may be replaced by other Soviet leaders - most commonly Gorbachev. There are 13 conundrums to do with Brezhnev.

Mikhail Gorbachev's name appears in 73 anecdotes. Most of the anecdotes in which he takes part involve the leaders of the Soviet Union and the United States visiting each other. In general he takes part in a number of older jokes about statesmen (37 such anecdotes). There are eight conundrums involving Gorbachev's name, but none of them is particularly well-known or relevant to him alone.

Russian statesmen appear in the school traditions competition material in 167 anecdotes and 38 conundrums. In addition to the more famous statesmen mentioned above, jokes about Yeltsin, Chernenko, Andropov, Kosygin, Sobchak, Yazov, Krupskaya, Dzerzhinski, Beria, Bulganin, Zhdanov, Podgorni, Gretchko, Ryzhkov, Ligachev, Zhirinovski, Catherine the Second and Kutuzov can be found in the material presently under examination. Their role, compared to that of the more famous men is, however, very small. Such anecdotes are rare and there is only one copy of each.

\section{Other countries' statesmen}

Statesmen from other countries are poorly represented in Estonian schoolchildrens' repertoir of anecdotes.

GERMAN politicians are mentioned in 21 anecdotes and 3 conundrums. The most common characters in these stories are Hitler (who appears in 10 anecdotes) and Marx (who appears in 5 anecdotes and 3 conundrums). Hitler acts in most cases together with Stalin, although the two are also interchangeable in one set of anecdotes. They are popularly considered as more or less equals, being despots of the same period. In anecdotes, Marx is usually connected with Engels or Lenin.

Anecdotes about Stirlitz and Müller (Müller - German Security Chief in WW II) form a group of their own. These jokes were inspired by the popular Soviet film "Seventeen Moments in of Spring", in which the brave Soviet spy (Stirlitz) deceives the highest echelons of the German army and the Gestapo and always comes out the winner. In terms of content, these stories belong to the realm of the absurd, although the political background is present.

AMERICAN statesmen appear in 35 anecdotes and 2 conundrums. No distinction is made between Bush, Reagan, Carter, Nixon, Roosevelt or Truman. The content of these jokes is mainly meetings of and conflicts between the leaders of the Soviet Union and the USA. The representative of the Soviet Union is the one who is most often deceived - only in a few cases does he outsmart his foreign counterpart.

OTHER COUNTRIES' political figures are mentioned also. A few times the English (Nelson, Churchill, Thatcher) and French (Napoleon, San-Martin, Mitterand) appear in anecdotes. Swedes, 
Italians, Romanians, Finns, Hindus, Cubans and other nations are represented by only one politician each.

\section{Estonians}

There are still very few anecdotes about Estonians in schoolchildrens' repertoir. They are mentioned in only 17 anecdotes, and of those 12 are specifically linked to only Estonian politicians. The most widespread of anecdotes about Estonian politicians is the pun in which the meanings of the names Toome, Väljas and Otsason are played upon.

There are three copies of the anecdote - again a pun - in which Rüütel (or Väljas) to to Gorbachev with the complaint that houses can no longer be built, because there is a lack of building material.

Four anecdotes (there are only one or two copies of each) involve Savisaar, two involve Käbin, and one each involve Lauristin, Lebedev, Meri, Vaino and Tõnurist.

There are three conundrums about Estonian politicians, two of which are of Estonian origin.

Toome - a leader of the Estonian Soviet Communist youth organisation; Secretary of Ideology of the Central Committee of the CP ESSR; Chairman of the Council of Ministers of ESSR during the "singing revolution".

Väljas - Soviet Estonian party leader, deputy of the Supreme Council of the USSR and of the ESSR; Secretary General of the CP of ESSR - successor in office to Karl Vaino during the "singing revolution".

Otsason - Estonian economist and statesman; Chairman of the State Planning Committee of the ESSR; President of the Bank of Estonia in 1990-1991.)

Rüütel - Chairman of the Presidium of the Supreme Council of the ESSR and of the Republic of Estonia.)

Savisaar - ex-Prime Minister of the Rep. of Estonia; member of the Supreme Council and Parliament of the Rep. of Estonia; founder of the Estonian People's Front.

Käbin - statesman and party officer in the ESSR; 1978-83 Chairman of the Presidium of the Supreme Council of the ESSR.

Lauristin - member of the Supreme Council of the Rep. of Estonia; deputy of the Congress of Estonia and the Parliament of Estonia; former Minister of Social Affairs of the Rep. of Estonia; founder of the Estonian People's Front.

Lebedev - deputy of the Supreme Council of the Rep. of Estonia; representative of the proimperialist Russians.

Meri - ex-Minister of Foreign Affairs of the Rep. of Estonia; President of the Republic of Estonia.

Vaino - Soviet Estonian party officer and statesman; Secretary General of the CP of ESSR.

Tõnurist - Soviet Estonian statesman; 1953-61 Minister of Agriculture; 1961 1st Deputy to the Chairman of the Council of Ministers of the ESSR. 


\section{THE SOCIALIST AND COMMUNIST SYSTEM}

Among those anecdotes which criticise the socialist and communist systems one can find anecdotes which contain sharp political material but in which there is no mention of any specific statesman or politician. There were 59 such anecdotes, and 78 such conundrums. It is interesting to note that conundrums outnumber anecdotes in this category. There are no well-known anecdotes, although there are many popular conundrums. The number of possible topics is very large, so the material can be subdivided into three groups:

1. Communism and the communist party;

2. The KGB, the army and the police;

3. politics and economy.

Among anecdotes which poke fun at communism and the communist party, one can find jokes about the absurdity of the communist system, about communists (communist party members), young communists, pioneers and "timurites" (Timur - the main character in A. Gaidar's "Timur and His Team".). Most of these anecdotes are represented with only a couple of variations each.

There are 26 anecdotes and 15 conundrums about the security organs (i.e. the KGB - translator), the police and the army in the school traditions material. The content of anecdotes about the army have mainly to do with the topic of avoidance of military service.

Police stories are clearly disdainful stories of buffoonery. The low education of the police is criticised, as well as their slow-wittedness.

Among anecdotes about the security organs one can find jokes dealing with the outsmarting of the KGB.

Anecdotes about the policy and economics of the Soviet Union tell of the state's aggressive foreign policy (the "assistance" given to, and the domination of, other socialist countries), innovations in economics (nourishment program - program to relieve the shortage of food in the USSR; cooperatives - at the period of disintegration of the Soviet Union many co-ops were created. Since private enterprises were not yet allowed, co-ops were the only legal way to act on the principles of "full self-support and self-funding") and elections Soviet-style.

\section{ANECDOTES ABOUT LIVING CONDITIONS}

Anecdotes in this group lack a clearer categorisation - they describe the tragi-comic situation created by the crumbling system. There are 33 anecdotes and 28 conundrums about living conditions. The main topics of these anecdotes are empty stores, ration cards and laziness at work peoples' everyday worries and problems.

The most popular anecdote among schoolchildren (157 copies) was from the three nation series of anecdotes. The selection of nations in the three nation anecdotes has the historical and political viewpoint. It is usually the case in nationality-anecdotes that other peoples are poked fun at or denigrated. These jokes are called ethnic, racist or foreigner anecdotes. In the context of the school tradition material, one may divide ethnic anecdotes into those which are chauvinistic (told about a nationality either smaller than or in subjection to one's own) and those which are political (told about the ruling nationality). Jokes in which an American makes fun of an American Indian or an African American, or in which a Russian makes fun of a Chukchi or Eskimo, can be classified as ethnic anecdotes with a chauvinistic slant. In ethnic anecdotes with political flavour, the Estonian pokes fun at the Russian, the Finn at the Swede, and the Irishman at the Englishman. 


\section{ABBREVIATIONS}

The school tradition material contains a large number of common abbreviations which have been unconventionally and humourously modified. There is a clearly visible political bent in these, which is, of course, predominant in the modification of political abbreviations (names of countries and parties).

In conclusion, the present formative period in the study of political anecdotes is very interesting. Anecdotes about Russian statesmen should begin to disappear, and in their place should appear Estonian-based ones. One may also expect a change in the field of political anecdotes due to the transition from a repressive society to a free one, in which political conflicts and differences of opinion can be resolved through a free press. In this context the importance of political anecdotes will decrease. It is clear that in a couple of years the situation with regard to political anecdotes will have greatly changed.

\section{Register of Children Political Anecdotes}

Material for the list of political anecdotes comes from the sources that is received by the competition of schoollore in 1992. The main groups of anecdotes are marked with capital letters, subdivisions with Roman numerals. In subdivisions the following classification is used: a) anecdotes, b) conundrums, c) gesture anecdotes. In subdivisions the anecdotes as well as conundrums are numbered successivly. After the anecdote type there is a number in brackets. It marks the guantity of different anecdote versions. (Exceptionally militial anecdotes have not the numbers marking the quantity of different versions, because their connections with political subject is quite vague and they have been put in the list later.) In front of the concrete type there is the combination of a number and a letter, which marks the anecdote type, related to the theme or character, that has parallels in other subdivisions.

\section{A. STATESMEN}

\section{RUSSIANS}

\section{Lenin}

a. Anecdotes. A II, a2; A II, a7; A V, a31; A V, a37; B II, a2; BII, a9; B III, a1; B VI, a3; C I, a1; C $\mathrm{I}, \mathrm{a} 5$.

1. A group of kindergarten children find a porcupine one day. The teacher asks them: "Who is that? There are a lot of songs, poems and films about him" - "So that's what you look like, Vladimir Ilyitsh!" (18)

2. Lenin rises from his coffin and goes to a bar. "Comrades, don't you recognise me?" - "Hey Vasja, look, a walking 10-ruble note!" (6)

3. Lenin phones Beria one evening: "Something terrible has happened - tomorrow is a day of voluntary weekend work, but my inflatable beam has been stolen!" [on days of "voluntary" weekend work, citizens were expected to do work for the benefit of the state - translator] (2)

4. Brezhnev wants to try out Lenin's coffin, so he whispers to Lenin: "V. I., revolution!" Lenin jumps up and disappears. When he returns, the coffin is occupied. Lenin says to Brezhnev: "Hey, medals are being distributed over there!" (2) 
5. Lenin shouts from on top of an armoured car: "Pedophiles and lesbians to the right, maniacs and rapists to the left!" Dzerzhinsky: "What should I do, I fall into both categories?" Lenin: "Come up onto my armoured car." (1) Compare with A X, al

6. A class of kindergarten children had just been taught that Lenin lived underground and prepared the revolution. One girl was not present at that class. She was asked: "What did Lenin do underground?" - "He caught mice." (1)

7. Lenin and Stalin/Gorbachev were travelling by train. Stalin needed to take a shit. Lenin recommended Stalin releave himself out the window. A little child said: "Mother, a fat-cheeked man is vomiting chocolate." (3) (A common topic, usually the main character is not a statesman.)

8. The teacher asks Juku: "Do you know Lenin? Marx? Engels?" Juku: "No, I don't! But do you know Hans? Or Jüri? Or Mihkel? The teacher: "No, I don't!" Juku: "Why are you trying to frighten me with your gang? I don't know your gang, and you don't know mine." (2)

9. Lenin and Stalin see from their tower that people are looking up at them with binoculars. When they come down from the tower they find out that actually it is pay-day and that what they thought were binoculars were the bottoms of vodka bottles. (1)

10. Lenin and Stalin are swimming across the ocean. They are nearing the other side. Stalin: "Can you make it the rest of the way?" Lenin: "No, let's swim back." (3) (Better known as a Petka and Chapayev joke. Chapayev - commander of a regiment and a brigade of the Red Army during World War I and the Russian Civil War.)

11. Lenin/Zhirinovsky and Kalevipoeg/a farmer are standing at the top of Great Munamägi. Lenin looks across the Gulf of Finland and says: "Life is good in places where we are not!" [in Estonian this is like saying "the grass is greener on the other side of the fence" - translator] Kalevipoeg: "Yes, life is indeed good where you are not!" (3) (Kalevipoeg - protagonist of the Estonian national epic.)

12. Lenin phones Stalin and asks: "Did you like the latest edition of "Iskra"?" - "Very soft paper!" says Stalin (1)

13. An elderly man is standing admiring Lenin's picture in a store window. A boy walks by. The elderly man: "Do you recognise (him)? The boy runs away, holding his nose, and says: "You farted, dirty old man." [the pun lies in the double meaning of the word "tundma" (to recognise) in Estonian: it means both to recognise a person, etc. and to notice a smell - translator] (1)

14. V. I. Lenin never tired of repeating: "There are only three real members of the Communist Party - Uljanov, Lenin and I!" (2)

15. A man wants to go to prison, but he is unsuccessful in his efforts. He is advised to bomb the Communist party, but when he arrives there it turns out that that has already been done. He is then advised to hijack an aeroplane, but it turns out that the pilot himself is a hijacker. Next he is advised to shout that Lenin and Stalin are in a garbage can. Lenin and Stalin/Gorbachev/Reagan/Brezhnev really are digging in a garbage can and stick their heads out and say: "We've been discovered." (23) $=\mathrm{A} \mathrm{V}, \mathrm{a} 23$

16. "Why are you afraid of uncle Lenin?" - "Well, he's immortal and loves children!" (1)

17. Lenin orders a package from the Red Cross to be given to children. - "But those are condoms!" Lenin: "Punch holes in them and give them to the mensheviks!" (2) 
18. Lenin, Stalin and Brezhnev are arguing which is better, a wife or a mistress. Lenin: "You tell your wife that you are going to see your mistress, and you tell your mistress that you are going to see your wife. But actually, you are going to the basement to study, study, study!" [there was a slogan in the Soviet Union - "study, study, study!" - translator] (1)

19. Lenin/Krushchev/a Chukchi, Stalin/Bush/a Mongol and Gorbachev/a Russian are starving in the desert. Lenin: "I don't like that Gorbachev." Stalin: "If you don't like it, don't eat it!" (7)

20. Lenin demonstrated how how one may rule. Stalin demonstrated how one must rule. Krushchev demonstrated that any idiot can rule. Brezhnev demonstrated that any idiot is not capable of ruling. (2)

21. A man/a Chukchi parks his Zaporozhets/skidoo in front of the mausoleum. The policeman says: "Here is Lenin/Stalin/Brezhnev/Andropov/Gorbachev and you dare to leave your car here." The man: "I have a combination lock on my car." (3)

22. "Lenin was good, Stalin was bad." - "But Gorbachev?" - "We'll find out when he's dead." (1)

23. At an art exhibition there is a painting "Lenin in Poland". The guide explains: "This is the hut in Razhliv, and these are Krupskaya's, and these Dzerzhinsky's legs." - "Where is Lenin?" - "Lenin is in Poland." (1)

24. The Americans buy Lenin's mummy. Lenin wakes up in America, and says: "Now that's the kind of Russia I wanted." (2)

25. The rule of Lenin: as if in a tunnel - darkness, but ahead there is light. Stalin's rule: as if in a bus - one person is driving, half of the passengers are sitting, the other half are shaking. Krushchev and Bulganin: as if in a plane - two are piloting, it makes you vomit, but you can't get out. Krushchev: as if at the circus - one person is talking, the others are laughing. Brezhnev: as if at the movies, all are waiting for the end of the show. (1)

26. Lenin wakes up in the mausoleum and sees an old lady: "Bring sausage!" The old lady returns with Gorbachev. Lenin: "I told you to bring sausage, but you've brought me a whole pig." (1)

27. "Let's go to the theater to see "The Living Corpse"." - "I'm tired of all that stuff, it's always Lenin, Lenin, Lenin." (1)

28. At the library, a woman asks for a book on folk dancing. - "Here's Lenin's "One step forwards, two steps backwards." (1)

29. A man finds his wife with her lover. She says: "You can't touch him, he's seen Lenin alive." (1)

30. An elderly person asks for help from Lenin. He is told that Lenin is dead. - "When an elderly person needs help, then he's dead, but usually it's said that he's immortal." (3)

31. Lenin/Hitler and Stalin/Brezhnev are in hell. Stalin is crying: "Lenin is in the kitchen and is forcing me to eat with a hammer and sickle." (4)

32. Lenin and Stalin are out fishing. Lenin has fat worms, since he stuck live electrical wires in the dirt to attract worms. Stalin got beaten up by some miners, because he stuck high voltage cables in the dirt. (1) (Better known as a Petka and Chapayev anecdote.)

33. Lenin is asked for at the Kremlin 3 times. It is answered that he is dead. - "Yes, I heard the first time you said that Lenin is dead, but it's so nice to hear." (1) Compare with D II, a2.

34. Gorbachev and Lenin / Jeltsin and Gorbachev / Rüütel and Gorbachev go for a walk. Thieves come. Gorbachev hides at the top of a tree, and Lenin hides underneath the tree. The thieves beat Lenin silly. The next time this happens, Lenin and Stalin change places. The thieves: "The one at 
the bottom already got beaten up, now let's give it to the one above." (5) (A common topic, usually the main characters are Petka and Chapayev.)

35. Lenin, Bush and Gorbachev / Gorbachev and Yeltsin / Gorbachev and Reagan are sleeping in the same bed. Bush spits upwards. Gorbachev gets hit. Gorbachev: "Warn us next time!" Lenin: "Warning!" B. and G. put their heads under the covers. Lenin farts. (3)

36. Lenin and Stalin / Bush and Gorbachev visit each other. There are three buttons in the toilet. It is forbidden to press the red button. Both press it, however. One of them gets kicked out of the toilet by a robot leg, and the other has his head pushed into the toilet bowl. (2)

b. Conundrums. A III, b2

1. What do Lenin/Brezhnev/Gorbachev and Karlsson have in common? - They both said: "Only peace!" (11)

2. What do a rat and Lenin/Kingissepp have in common? - Both operated underground. (43)

3. What was under Krupskaja's skirt [K. was Lenin's wife - translator]? The first "Lenin's corner" ["Lenin's corners" were corners, in schools, offices, etc., where Lenin's picture and the Soviet flag were placed - translator] (2)

4. Why are some beds wide enough for three people? - Lenin is always with us. (36)

5. How tall was Lenin/Brezhnev/Gorbachev? - "Up to here" on everybody [up to the neck, i.e. everybody was fed up with him - translator]. (6)

6. What is the difference between Lenin and a schnitzel? - They look the same. (1)

7. Who was the bigger revolutionary, Lenin or Toots? - Toots, since Toots painted the whole world red, Lenin only Europe [the reference is to the character Toots in Oskar Luts' series of books

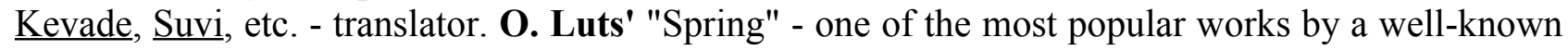
Estonian author. Toots - a character in O. Luts' "Spring".]. (2)

8. What do Lenin and a fly have in common? - Both were struck down. (1)

9. Who acquired a flat after the XIXth Congress? - Lenin, since Stalin was kicked out of the mausoleum. (1) (Stalin, who was originally buried beside Lenin, was re-buried after his personality cult was condemned at the XIXth Congress of the Communist Party of the Soviet Union.)

10. What is "Kuldne Trio" ["Golden Trio" is an Estonian comedy troupe - translator]? Lenin, Stalin and Brezhnev. (1)

11. Why was Lenin bald? - 1. The floor boards were unplaned. 2. He worked underground. (3)

12. What did Lenin think when a bird did a dropping on his head? - Isn't it good that cows don't fly. (1)

13. In what language did Marx and Lenin correspond? - They didn't, they lived at different times. (1)

14. How does one know that it is warmer in Tallinn than in Tartu? - In Tallinn, Lenin's statue is wearing a jacket, but in Tartu his statue is wearing a coat. (3)

15. What did Lenin think when he got hit in the head with a piece of railroad track? - BOMB!!! (1)

16. What anniversary was celebrated in 1974? - 50 years without Lenin. (1)

17. Can men give birth? - Yes they can. Lenin gave birth to Leninism, Marx to Marxism, and Brezhnev is on maternity leave and waiting to give birth to communism. (3) 
18. The night before the opening of a statue of Lenin, the head of the statue is stolen. A new head is searched for in great haste. When the statue is opened, people start to laugh. Why? - this Lenin has two hats: one on his head and the other in his hand. (1)

19. Name Russian heroes of the 20th Century! - Vladimir Smart, Joseph the Terrible, Nikita Corn, Leonid Peacemaker, Juri Longarm, Mikhail Renovator. (1) (This joke refers to Lenin, Stalin, Krushchev, Brezhnev, Andropov and Gorbachev's Russian nicknames.)

\section{Stalin.}

a. Anecdotes. A I, a7; A I, a9; A I, a10; A I, a12; A I, a15; A I, a18; AI, a19; A I, a20; A I, a21; A I, a22; AI, a25; A I, a31; A I, a32; A I, a36; A III, a3; A IV, a34; A IV, a43; A V, a13; A V, a37; C I, a1;

1. Stalin made two mistakes in the course of the Second World War: the first in showing Russian Ivan [= generic Russian - translator] Europe and the second in showing Europe Russian Ivan. (1)

2. During an excursion to hell, the guide is asked: "Why is Hitler up to his neck in boiling water, but Stalin only waist high?" The guide: "Stalin has climbed up onto Lenin's shoulders." (3)

3. Stalin isn't allowed into heaven after his death: "You belong in hell!" Soon there is a herd of devils at the gates of heaven saying: "We request political asylum..." (1)

4. Churchill, Stalin and Ceausescu are in hell. Later they meet up again. Churchill is finding it difficult to sit, but Stalin is chuckling. "Well, was it painful?" - "It was indeed, for every lie they put one needle under your fingernail - they had put a sewing machine aside especially for Ceausescu." (1)

5. A man is complaining: "There are no eggs, there's no milk or meat either..." Another man says to him: "In Stalin's time you would have been shot for saying that." The first man: "That's right, nowadays there aren't even enough bullets to go round." (1)

6. Stalin rises from the dead. Gorbachev offers him his position. Stalin: "First of all, we'll hang Yeltsin and next we'll paint the Kremlin green." Somebody asks: "Why green?" Stalin: "Good, I didn't think there would be any objections with regard to my first proposal." (1)

7. Stalin rises from the dead. An elderly lady meets him in the street and asks: "Do you remember me, I'm Krupskaya?" - "Oh yes, and I remember your husband Krupsky too!" [If a woman is called Krupskaya in Russia, then it can be expected that her husband is Krupsky. Actually, Krupskaya was Lenin's wife - translator] (1)

8. Stalin has lost his pipe. Beria promises to find it for him. Later Stalin finds his pipe. Beria: "Don't worry, Comrade Stalin, two have already admitted and I'll see to it that two more will also admit!"

9. Stalin and Truman are arguing whether there is more freedom in the USSR or in the USA. Truman: "In the USA, anybody can shout "Down with Truman!" in front of the White House." Stalin: "Anybody can shout "Down with Truman!" in Red Square too." (2)

10. Churchill, Roosevelt and Stalin / Gorbachev and Reagan/Bush are driving in a car. A cow is blocking the way. Stalin whispers something to the cow - the cow moves aside. The others: "What did you say to her?" Stalin: "I promised to send her to the kolkhoz, if she doesn't get out of the way." (7) 
11. Stalin / Hitler visits a mental institution. Some of the patients sing the Soviet anthem. Stalin: "Why aren't the others singing?" The psychiatrist: "They're already sane." (9)

12. One of Stalin's bootlaces comes untied at a parade. Zhdanov suggests requesting help from the pioneers. A pioneer ties up his bootlace. Stalin: "What's your name?" - "Misha Gorbachev." (1)

13. There were three powerful men in the Europe of 1939 - Stalin, Hitler and Mussolini. Peace was meant to come when Hitler and Stalin killed each other in a duel on Mussolini's grave. (1)

14. Stalin enters an outhouse made of wood. The door creaks. - "A musical toilet!" The toilet bowl squeaks. - "A singing toilet bowl!" He leaves the outhouse, and it collapses. "A folding outhouse!" (1) (The topic comes from a three-nationality anecdote; he who builds the best toilet is freed from prison, the main characters are a head of state or prison guard. Very common.)

15. Stalin is travelling in a German train which doesn't have a toilet. He relieves himself into a towel. In Germany and Poland the towel was untouched. In Russia the towel is stolen. (1) Compare with A II, a18 and A Vi, a1.

16. Stalin and Lenin / Gorbachev and Bush are in a boat. Stalin feels a call of nature. Lenin suggests that he relieve himself over the edge, wipe himself with his finger and wipe his finger against the outside of the boat. Stalin gets a sliver in his finger and puts his finger in his mouth. (2) (The main characters may also be Petka and Chapayev.)

17. Check-up at the pig-farm. By the last pig is a picture of Stalin. Stalin, who works there, explains: "This pig looks so much like me. I put my picture up beside him, otherwise some people might not notice the similarity." (1)

18. Tsarina Katarina the Second pushes Stalin off his cloud, because in her opinion, the slogan "Stalin's great cause" [in Estonian the word for cause also means penis - translator] is not accurate. Stalin sets down his backpack. Immediately, it is stolen. "I'm back in the homeland!" he happily sighs. (1) Compare with A VI, a1

19. Stalin is hunting with two comrades. They shoot a bear, and then skin it. The comrades go to bring a stretcher. They return to find that the skin is no longer there. "Where is the skin?" Stalin: "What skin?" - "We came hunting, right?" - "Yes, we did." - "We shot a bear, right?" - "Yes, we did." - "We skinned it, right?" - "Yes, we skinned it." - "Where's the skin then?" - "What skin?" (1)

20. A child sees pictures of Marx and Stalin, and shouts: "Look, a hairy cat!" His mother teaches him which is Stalin and which is Marx. A cat runs across the street. The child: "Look, Stalin's running!" (1)

b. Conundrums. A I, b9; A I, b10; A I, b19.

1. What did Stalin collect? Anecdotes about himself. He had two hard-labour camps full of them. (2) Compare with A IV, a40.

2. What is Stalin most afraid of? The day the Chinese learn to make war like Jews, and Jews learn to reproduce like the Chinese. (1) 


\section{Krushchev.}

a. Anecdotes. A I, a19; A I, a20; A I, a25.

1. Krushchev is at the pig farm. The little pigs squeal: "Rutsch, Rutsch, Rutsch!" A big pig grunts: "Shoff!" (1)

2. Krushchev is at the pig farm: "What, are these pigs? Pigs should be like this!" - and gets down on all fours. (1)

3. Krushchev/Stalin developed a liking for little Western cars. He demanded that Russia begin to produce small and round cars: "Now look, this is what a car is meant to be like!" - and gets down on all fours. (2)

4. Fidel Castro is visiting Moscow. Once alone with Krushchev, he removes his wig and false beard and sighs: "I can't do this anymore!" Krushchev: "You must, Fedya, you must!" (1)

5. Krushchev is at a banquet in India. Under the table, he caresses the knee of a dancer. Suddenly he hears a whisper: "Comrade Krushchev! Major Pronin reporting! (1)

6. A co-worker meets Krushchev/Brezhnev in a corridor of the Kremlin and says: "Christ rose from the dead!" [Russian Orthodox Christians have the custom of saying this to each other at Easter translator] - "Thanks for telling me!" Another man walks by: "Christ rose from the dead!" - "I've already been notified, thanks!" (2)

7. Krushchev/Gorbachev and Reagan/Bush are in America. Krushchev is given permission to shoot all alcoholics. The next day comes anannouncement on the radio: "An unknown bald gangster shot two Russian tourists." (3)

8. Krushchev and the US President are standing by a field of tulips. The US President: "Tulips that's the USA, thistles - the USSR."Krushchev wipes his bottom with tulips. "Try to do the same with the Soviet Union!" (1)

b. Conundrums. A I, b19; A IV, b2.

1. Who is the greatest magician in the world? - Krushchev, who sowed in virgin land, but harvested in Canada. (2) Compare to A IV, b8.

2. Why did Krushchev/Lenin/a Russian wear a straw hat? Formerly, one used to always cover manure with straw. (16)

3. What does Nikita's haircut look like? - Like the harvest of 1963. (1)

4. In what pocket does Nikita keep his comb? - He doesn't have a comb, he's bald. (1)

\section{Brezhnev.}

a. Anecdotes. A I, a4; A I, a15; A I, a18; A I, a20; A I, a21; A I, a25; A I, a31; A III, a6; A V, a37; B II, a1; B II, a3; B II, a9; B VII, a10; C I, a1; D I, a1.

1. The opening of the 1980 olympic games. Brezhnev: "O! O! O! O! O!" An advisor: "Those are the olympic rings, the text starts lower down!" (7)

2. After a speech, Brezhnev is reproving his advisor: "I asked for a 15 minute speech from you, but you gave me one that lasted an hour!" - "But there were four copies there!" (3) 
3. The doorbell rings at Brezhnev's residence. Brezhnev takes a piece of paper and reads: "Who is it?" (3)

4. Brezhnev is receiving Thatcher: "Most honoured Mrs. Gandhi!" "She's not Gandhi, she's Thatcher!" - "I can see that, but here it's written Gandhi!" (1)

5. Brezhnev invites Sophia Loren to come and visit him. The actress sets as a condition that Brezhnev must first open the borders of the USSR. Brezhnev: "She must want us to be alone!" (1)

6. Brezhnev returns from India with a red dot on his forehead. B: "In India they pointed at my forehead and said that I was missing something there." (1)

7. Brezhnev/Gorbachev announces that since the Americans were the first to reach the moon, the Russians must be first to the sun. - "But we'll burn to bits there!" Brezhnev: "We've planned for that. Take-off will be at night." (5)

8. Brezhnev is making a speech at a meeting of the Politburo: "Comrades, I am not satisfied with you. Yesterday at Suslov's funeral - by the way, where is he? - I was the only one who danced with his widow. (1) Compare with B II, a1.

9. Brezhnev disappears into the forest after a hunting trip. Animals are sent to search for him. Rabbitt announces: "I haven't seen Brezhnev, but Wolf is shitting medals." (4)

10. A light bulb burns out in the White House. Nixon presses a button, a workman comes and replaces the light bulb. Nixon gives the man 5 dollars. A light bulb burns out in the Kremlin. Brezhnev's bodyguard calls a workman and searches him. The workman replaces the light bulb. Brezhnev gives himself an Order of Lenin, and gives another to the workman. For good measure, Brezhnev gives himself yet another medal. (1)

11. Brezhnev sees Karlsson flying above his summer residence: "Who are you?" - "Karlsson." Brezhnev thinks for a moment, then says: "Ahhaa, now I remember, but where is your friend Engelsson?" (2) * (this refers to Karl Marx and Friedrich Engels.)

12. Brezhnev is on tour in Central Asia. He is greeted with: "Salam aleikum!". He responds: "Aleikum salam!" [in Central Asia this is a traditional greeting - translator] A dissident from the crowd shouts: "Gulag Archipelago!" Brezhnev responds: "Archipelago Gulag!" (2) (The Gulag Archipelago is the name given to the prison camps of the Soviet Union.)

13. Brezhnev is eating fish at a gala dinner. The waiter pushes Brezhnev's knife closer to him. Brezhnev: "I happen to know that fish is eaten with two forks." The waiter: "But one takes salt with one's knife." (1)

14. Brezhnev refuses a medal: "I haven't earned a gold nose-ring yet." (1)

15. Brezhnev looks in a mirror at an art exhibition: "What monster is that? - "That's you, Comrade Brezhnev." (1)

16. Brezhnev goes to work with one black shoe and one brown shoe. His secretary suggests that he change them. B: "But there's an identical pair at home." (1)

17. Brezhnev's wife answers the telephone at home. The caller is a woman who had been in the same class with Brezhnev at school. - "You're a prostitute, not a classmate. Ljonja never went to school." (1)

18. Brezhnev is making a speech to journalists: "It is said comma that I read my speeches from paper period. That dash is wrong exclamation mark." (1) 
19. A Brezhnev stamp has been made, but nobody is able to make it stick. Some spit on the wrong side, and some lick the wrong side. (1)

20. Brezhnev is sunbathing naked on the private beach for Politburo members, with a hat covering his face. A dog licks his balls. Brezhnev lazily says: "Now that's a bit much, comrades!" (1)

21. Brezhnev's last decree: "Place me in my coffin belly-down! That way it'll be easier if you wish to kiss my ass ten years from now." (1)

22. Brezhnev is dead. The Russians don't want to bury him. In the end the Jews are willing to do it. The Russians aren't agreed, however: "You buried Jesus and he rose from the dead three days later." (1)

23. Brezhnev and the Sun greet each other in the morning. In the evening, the Sun says: "You there, shut up, I'm already in the West!" (2)

24. Brezhnev asks the pope: "Why do people believe in the Catholic paradise, but not in the Communist one?" The pope: "We don't show them our paradise." (1)

25. Brezhnev/a Jew must choose, whether he wants to go to heaven or hell. In heaven, angels read the newspaper out loud to the saints. In hell, there are beautiful women, drinking and cards. B. chooses hell. Once there, he is immediately thrown into a cauldron of boiling water. B: "This is not at all like what I was shown!" - "That was our propaganda station." (2)

26. Brezhnev must choose which torture to suffer in hell. He sees sleeping people who must roll over every time a joke is told about them. - "I'd like a place by that gyroscope over there." - "That's comrade Chapayev." (1)

27. Brezhnev complains to an alcoholic that he doesn't have a mausoleum. The alcoholic promises to build one for him for 3 rubles. In the morning, Brezhnev sees that LYONIN is inscribed on the front of the mausoleum [Lyonya is the Russian nickname for Leonid - translator]. (1)

28. Brezhnev/Gorbachev and an alcoholic bet on whether the alcoholic can get 1 bottle, 3 bottles or a whole case of vodka from the store. The alcoholic wins. The third time he points out Brezhnev, who is standing outside the store window, to the salesperson: "I don't want the vodka for myself, but for my friend." (2)

29. Brezhnev's mother is visiting her son. They are surrounded by incredible luxury. His mother starts to cry: "1917 just came to mind. Perhaps the Communists will come again." (1)

30. Brezhnev/Gorbachev feels a call of nature at a Pugachova concert. When he wants to go to the toilet, P. sings: "Where are you going?" Eventually B. cannot resist and says "To the outhouse!" (4)

31. A peasant asks Brezhnev/Gorbachev what communism/perestroika is. B. explains that now trams go every 15 minutes, but 5 years from now they will go every 10 minutes, and 15 years from now they will go every 5 minutes and 20 years from now they will go all the time. At home, the peasant explains to another peasant: "Now beggars beg every 15 minutes, etc. That is communism."

32. Milkmaid Leida wrote a letter to Brezhnev. Now she writes LOLL on her house every morning [loll means stupid in Estonian - translator]. Leida: "I didn't write LOLL, I wrote: "Leonid, I'm in the Barn. Leida!"' [in Estonian the letters LOLL are the first letters of the words "Leonid, I'm in the Barn. Leida" - translator] (1) see also D IV, b21. (Leida Peips was a milkmaid at the Viljandi Model State Farm. She completed the five year work plan in 4 years and received the title of Socialist work hero in 197?. She actually did write a letter to Brezhnev, and got a response too.) 
33. Brezhnev is on his way to the barn to see Leida and falls in a pile of shit. 3 boys help him out. In return one boy asks for a motorbike, the second a car, but the third wants a straight jacket: "When I tell my father that I helped Brezhnev out of a pile of shit, he'll kill me!" (2) see also D IV, b21.

34. Brezhnev/Stalin was visiting Reagan/Hitler. He developed a liking for the toilets there. For Reagan's visit B. ordered a toilet to be built, in which a janitor would wipe one's bottom. R.'s face was wiped too. (2)

35. Brezhnev/Gorbachev are visiting Reagan/Bush. Reagan offers B. the brains of a black person to eat. In Russia, B. wants to offer Reagan the brains of a policeman. The skulls of 30 policeman are cracked open, but none of them had brains. (6)

36. Brezhnev/Gorbachev and Reagan/Nixon/Bush run a race. The Soviet newspapers later announce: "B. won second place, but Reagan came in second to last!" (3)

37. In Russia, Reagan sees men in striped clothes working. Brezhnev says that they are sailors. Reagan: "As far as I know, the stripes on sailors' shirts are the other way round." (1)

38. Brezhnev and Nixon are standing by Niagara falls. Both of them order their bodyguards to jump over the edge. The American refuses, saying: "I have a family, children." The Russian has to be restrained. Nixon: "Why did you want to jump?" - "I have a family, children." (2)

39. Brezhnev/Gorbachev and Carter/Reagan/Bush meet in Vienna. Carter explains that he chooses his administration by using IQ tests. Carter asks Vance: "Who is your father's son, but is not your brother?" - "I am." Brezhnev asks the same question of Andropov/Vaino/Yeltsin/Roshkov/Ligachev. Andropov doesn't know. B: "Vance, of course." (4)

40. Kekkonen is proud that there are two collections of anecdotes about him. Brezhnev: "I've built 8 hard-labour camps for those who tell anecdotes, the ninth is still being built." (1) Compare to A II, b1.

41. Brezhnev/Gorbachev buys himself a car which comes to a halt when one says "damn it", and starts moving forward when one says "thank god". B. is nearing a cliff: "Damn it!" The car brakes. B. heaves a sigh of relief: "Thank god!" (4) (A common topic, although the main character is usually not a statesman.)

42. Brezhnev/Gorbachev is flying in an aeroplane. The bottom falls out of the aeroplane. All hold on wherever they can. Brezhnev coughs, and all applaud... (29)

43. Brezhnev/Gorbachev/Stalin is flying in an aeroplane. All of a sudden, a devil starts to saw away at a wing of the aeroplane. B. speaks with him and the devil disappears. Brezhnev had promised to send him to the BAR for being such a good workman. (5) (BAR [Estonian \& Russian initials BAM - translator] = Baikal-Amur Railway, a railway line which was a Komsomol shock-work project.)

44. Brezhnev wants to see how Soviet people live. Seeing a good-looking house, he asks the boy who lives in the house to tell his father that they have him to thank for living so well. The boy: "Grandma, grandma, uncle Paul from America has come to visit!" (1)

45. Brezhnev is walking with a donkey. A farmer: "Doesn't it feel strange to be walking with that cow?" B: "But that's a donkey." The farmer: "I'm not talking to you, I'm talking to the donkey." (1)

46. Brezhnev is walking in Leningrad. At 12:00 noon he hears shots. He is told that the shots came from the Peter-Paul fortress. Another day the same happens. B. expresses surprise: "Didn't they hit their target the first time?" (1) 
47. Brezhnev is doing a crossword. A one-eyed general from antiquity - Hannibal. A one-eyed English admiral - Nelson. A one-eyed Russian general - Kutuzov. B. thinks: "If one knocked one of Gretshko's eyes out, would he become a famous general?" (1)

48. Brezhnev visits a collective farm. "How is life here?" he asks jokingly. "Good," the people answer, jokingly. (2)

49. Brezhnev: "Soon we will live much better than we do now..." - "But us?" asks an old man. (1)

50. Miners are on strike, demanding bread and milk. Their demands are met. Then goods in short supply are demanded. That demand is also met. The demands of the third strike are oranges, bananas, etc. Brezhnev: "But oranges and bananas don't grow in Estonia." (1)

51. A Russian and a Chinese boy are standing on the Sino-Soviet border. The Chinese boy: "I have a rice pie!" - The Russian boy: "But we have Brezhnev/Gorbachev!" The Chinese boy: "We might get Brezhnev soon too!" The Russian boy laughs: "In that case you won't have your rice pie!" (2)

52. Brezhnev's/Juku's parrot is rude and curses Podgorny and Kosygin. B. puts the parrot in the refrigerator while Kosygin is visiting. The parrot: "Try to be rude once you've been to Siberia!" (2)

53. Brezhnev has a tree painted red. Reagan has the name "Marlboro" added. Brezhnev has "Sdelano v SSSR" [= made in the USSR - translator] written on the tree. Reagan adds: "By license of Phillip-Morris company." Brezhnev writes: "The Ministry of Health of the Soviet Union warns that smoking is harmful to your health." (1)

b. Conundrums. A I, b1; A I, b5; A I, b10; A I, b17; A I, b19.

1. What is the longest joke? - Brezhnev's speech. (1)

2. Is it possible to wrap an elephant in newspaper? - Yes, if the newspaper contains Brezhnev's/Krushchev's/ Gorbachev's speech. (3)

3. What sound is made when Brezhnev gets hit on the head with a piece of railway track? "BAM..." [BAM are the Estonian \& Russian initials for "Baikal-Amur Railway" - see Brezhnev anecdote 43 - translator] (1)

4. What is the difference between Baskin [an Estonian comedian - translator] and Brezhnev/Gorbachev? - Baskin is smart and plays the fool, Brezhnev is an idiot and pretends to be smart. (3)

5. Why were the streets of Moscow closed? - Brezhnev was learning to ride a bike. (1)

6. Why was Moscow's main swimming pool closed? - Brezhnev's picture was being developed for the Congress of People's Deputies. (1) Compare with A LIX, a2

7. Why did Brezhnev receive the title of People's Artist? - He is the best at playing marshal. (1)

8. Did Brezhnev receive the Nobel prize for agriculture? - Yes, because he was able to work a miracle - he sowed wheat in the Ukraine, but harvested it in Canada. (1) Compare with A III, b1.

\section{Gorbachev.}

a. Anecdotes. A I, a7; A I, a19; A I, a21; A I, a22; A I, a26; A I, a34; A I, a35; A I, a36; A II, a6; A II, a10; A II, a12; A II, a16; A III, a7; A IV, a7; A IV, a28; A IV, a30; A IV, a31; A IV, a35; A IV, a36; A IV, a38; A IV, a39; A IV, a41; A IV, a42; A IV, a43; A IV, a51; A LVII, a2; B VII, a4; B VII, a5; B VII, a10; C I, a1. 
1. Gorbachev is walking in the street with a parrot on his shoulder. Yeltsin says: "You really have disguised your wife very well." (2)

2. Gorbachev wants to fly to Moscow with his wife. There is a bomb threat. Gorbachev sends a black man and a monkey to Moscow in their place. People say, surprised: "You are so tanned. We wouldn't have recognized you had it not been for Raissa Maximovna." (3)

3. Gorbachev enters the sauna. The other men place their water buckets in front of their privates. "We thought you were with Raissa." (12)

4. Gorbachev's wife doesn't want to let him go to Estonia, since no Russian has ever returned from there. Gorbachev: "Then I'll take you along." (1)

5. Gorbachev and Raissa are flying in an aeroplane. Raissa and Gorbachev: "If we threw vodka out of the plane, everybody would kiss our hands and feet." The pilot: "If I threw you two out of the plane, everybody would kiss my ass." (1)

6. In Red Square, Alla Pugachova passes a woman wearing an expensive fur coat. Pugachova asks her where she bought her fur coat: "I am Pugachova, why don't you answer me?" - "I am Gorbachova." (1)

7. Reagan wants to give Gorbachev a limousine as a present. G. refuses the gift. Reagan suggests paying one dollar for it. Gorbachev has a five-dollar bill. Raissa: "For that money, give us four more limousines." (1)

8. Gorbachev is crying in Red Square. Reagan: "What's wrong?" - "Raissa lost our sugar ration cards!" (1)

9. Gorbachev is visiting Bush. B. says that tractors in the US drive all day from one end of a field to the other. G: "We also have tractors like that." (3)

10. Gorbachev and Reagan visit each other and press forbidden buttons. G. receives a bruise, but nothing happens to R. Reagan goes to buy a plane ticket home. The salesperson says in a surprised tone: "Washington? That doesn't exist anymore." (3) Compare to A I, a36.

11. Reagan and Gorbachev are playing "battle of the cities" [presumably along the lines of "battle ships" - translator]. City after city is blown up. R: "A7!" - Gorbachev's voice is no longer to be heard on the other end of the line, instead only a busy signal. (1)

12. Gorbachev and Reagan/Bush are arguing whose country has the best thieves. A silver cup is stolen from G. in the underground. G. gives R. a "Zaporozhets" car. R. looks under the hood: "The best thieves are in Russia, they can steal a motor while you are driving." (9) ("Zaporozhets" is a make of Russian car, the motor of which is at the back of the car.)

13. Bush/Reagan and Stalin/Gorbachev are arguing who has the best pilots. Bush's men do death dives. Gorbachev asks a madman to fly. The madman falls out of the cockpit and hangs from a wing. G: "He's repairing the wing." The madman falls to the ground. G: "He went to get a wrench."

14. Gorbachev asks Bush whether the Americans would build a sanatorium in Russia, if they were to be paid in hard currency. - "For hard currency we could even build communism for you." (2)

15. Bush/Reagan offers Gorbachev/Yeltsin some watermelon. Gorbachev puts his pips on Bush's plate. G: "What makes you so hungry?" B: "You're hungrier, you even ate the pips." (3) 
16. Bush and Gorbachev are in Malta. G. is wearing a t-shirt with the letters "MIR" ["peace" in Russian - translator] written on it. Gorbachev explains to Bush that those letters mean "Misha and Raissa". (1)

17. Gorbachev asks Reagan where the money for his visit came from. Reagan explains that $\$ 10000$ was set aside for building a bridge, but in the end it was built for only $\$ 5000$. Soon Reagan is visiting Gorbachev. R: "Where did the money for our drinking come from?" - "Look out the window, there should be a bridge there." (1)

18. Bush is visiting Gorbachev. There he is shown a prison camp which is disguised as a Communist young pioneer camp. Bush asks a prisoner: "How many years do you have?" [in Estonian this also means "how old are you" - translator] - "15." - "I'd give you 45." [in Estonian this also means "I'd guess you were 45 years old" - translator] - "And I'd give you a beating, if that pioneer leader wasn't up there in that watch tower." (1)

19. Bush, Mitterand and Gorbachev are talking. B. says that an American worker makes 2000 dollars a month. 1000 of that goes to pay for the house and car, but what the worker does with the rest is up to him. M. tells the same story. G: "In the Soviet Union, people make 1000 rubles a month. Where they find the rest is up to them." (2)

20. Gorbachev, Bush and Kohl are in hell. Each of them phones home. G.'s call is the cheapest, since his is a local call. (1)

21. Gorbachev is visiting Bush. There is a flower composition on the window sill. Bush: "The red carnations are flowering America, the prickly cactus starving Russia." (1) Compare to A III, a8.

22. Gorbachev enters his office to find Ivan Sussanin waiting for him. Gorbachev: "If I had known you were coming I would have assembled the Politburo in your honour!" - "Yes, assemble them, then let's go." [Ivan Sussanin was a Russian hero who, in 1613, led the soldiers of the Polish army into a bog, where they killed him - tranlator] (1)

23. A man wants to go to prison. In the street, he shouts that Gorbachev is an idiot. G: "Everybody knows that Russians are idiots." Then the man shouts that Reagan and Gorbachev are in the garbage can. R. and G. stick their heads out of the garbage can and shout: "You guessed!" (1) Compare with A I, a15.

24. Gorbachev is in the desert and terribly thirsty. Suhhov says: "We don't serve alcohol before two in the afternoon." (1) (This refers to the Anti-alcoholism law, by which vodka could be bought only after two o'clock in the afternoon.)

25. It is Gorbachev's birthday. His wife suggests offering something refreshing to the guests. G. opens a window. (1) (Originally a joke about an imaginary people called Gabrovs.) [the name Gabrov comes from the town Gabrov, in Bulgaria, which now holds an annual humour festival translator]

26. The dictator of a socialist state returns from Moscow and asks for a birthmark to be imprinted on his bald head. Gorbachev had apparently answered his question as to how affairs of state could be managed to the satisfaction of the people by pointing to his forehead: "There's got to be something up here." (1) Compare with A IV, a6.

27. When abroad, Gorbachev sees a punk whose shirt bears the inscription "MIR KPSS", which apparently stood for "Mikhail and Raissa, stop perestroika, neighbours are laughing." [in Russian perestroika also means renovation - translator] (1) 
28. Gorbachev is on an excursion to hell. There are guards posted by the Latvians' and Lithuanians' cauldrons to keep them from climbing out. There is no need for a guard by the Estonians' cauldron, however. When anybody tries to climb out, the others pull him back in. (1)

29. In the jungle, Gorbachev meets King Kong, who lifts him onto the palm of his hand and asks him to sing. Gorbachev sings: "A corpse is a corpse..." King Kong claps and sings: "La-la-la-lala..." (5)

30. Gorbachev/a kindergarten teacher asks kindergarten children where the best toys, candies and wages can be found. - "In the Soviet Union." One girl starts to cry: "I want to live in the Soviet Union too!" (4)

31. Gorbachev is walking with his children in the mausoleum. His son asks: "Will you be buried here?" Lenin shouts: "This isn't a dormitory!" (4)

32. Gorbachev is dancing. A lady requests that he take his socks off, because they stink. The lady: "You didn't take them off." G: "Yes I did!" and takes them out of his coat. (1) (The main character may also be Chapayev.)

33. At school, Juku had to remain after class one day. His father tells him that when he was Juku's age, he was already going to university. Juku: "But Gorbachev was already president by your age."

34. Ivan the peasant promises Gorbachev that he will free Russia of its three greatest problems alcoholism, the shortage of housing and church-going - in three days. He was able to do all this by allowing vodka to be freely bought and sold - alcoholics drank themselves to death, by opening the borders - those who remained had no problem finding a place to live, and finally by putting a sign up on churches which said "HONOUR THE CENTRAL COMMITEE OF THE COMMUNIST PARTY OF THE SOVIET UNION" - the people avoid churches. (1)

35. Gorbachev visits a mental institution. An insane man chases after him with a chair. When he finally catches up to G., he says to him: "Please sit down!" (2)

36. Gorbachev visits a mental institution. The insane all have broken mouths, because they have learned a new game. An insane man draws a circle on a rock and says: "Jump through the hoop!"

37. Gorbachev/Brezhnev/Lenin and Stalin/Reagan are flying, looking for a place to drop a bomb. They cannot drop it on a kindergarten or school. They drop it on a mental institution. Afterwards, a madman can be heard laughing outside: "I farted and the institution blew up." (11)

38. Gorbachev meets the emperor of China. The emperor: "HUI HUI!" [hui means "penis" in Russian - translator] G. responds: "SAM HUI!" [sam means "yourself" in Russian - translator] The emperor: "Where's Gorbachev then?" (2)

39. Gorbachev says at a convention: "By 1990 we won't have any meat products, by 1991 we won't have any milk products, by 1992 we won't have any bread." A voice from the audience: "Let's start to work [also means "we are going to have to work..." - translator] for 10 hours, 16 hours and then the whole day!" Gorbachev: "Where do you work, comrade?" - "At the crematorium/funeral chapel." (2)

40. Gorbachev is inspecting a factory. He asks a lathe operator whether he would still be able to work if he had drunk one bottle or two bottles of vodka. - "Yes I could." - "How about three bottles?" - "What are you nagging me for, you can see that I'm working." (1) 
41. Gorbachev is smuggling a marmot into the United States. He hides the animal in his pants. During the trip he screamed with pain a number of times. Afterwards, he explains to Raissa that he screamed the first time when the marmot found a hole to dig himself into, the second time when the marmot found some nuts and tried to break them open with his teeth and the third time he screamed when the marmot tried to pull the nuts into his hole. (1)

42. Gorbachev/Hitler ordered his parrot to learn three sentences if he wanted to come along on a visit to America. The parrot did as requested. During the visit the parrot says: "So damn many Russians." G. takes out his gun. The parrot: "Shoot the Red Guard soldier." G. faints. The parrot: "Piss on him, he's still alive." (2)

43. The German president taught his parrot three sentences. Gorbachev came to visit. The parrot: "G. is stupid!" G. throws pillows at the parrot. The parrot: "The first one missed, the second one missed, the third was a hit!" G. falls. The parrot: "A happy landing!" (1)

b. Conundrums. A I, b1; A I, b5; A I, b19; A IV, b2; A IV, b4.

1. What is a Gorbushka? A pact between Gorbachev and Bush. (1)

2. What do a fly and Gorbachev have in common? Both get beaten with newspapers. (1)

3. What is water with power in the middle? - Gorbachev/a policeman in the bath. (1)

\section{c. Gesture anecdotes.}

1. Bush and Gorbachev are in an aeroplane. Bush shakes his fist at Gorbachev, and G. shakes his fist at Bush too. Bush shakes two fists, but G. points at his temple. G. tells his wife: "Bush gestured that he was going to beat me up. I gestured the same to him. He gestured that he was going to beat me up with two fists. I gestured that he is stupid." Bush tells his wife: "I gestured to G. to keep hold of the state, and he indicated that he would. I told him to hold on with both hands. He gestured that I'm stupid to suggest that, because he doesn't have the strength." (2)

2. Gorbachev meets a Hindu. The Hindu holds up one finger. G. holds up two fingers. The Hindu makes a fist. G. imitates waves with his hands. G. tells his wife that he met a madman who gestured that he would throw a dart at him. G., in return, gestured that he would throw two darts at him. The Hindu gestured that he would throw a stone at him. G. gestured that he would throw the Hindu into the sea. The Hindu tells his wife that he met a madman: "I asked him whether he was a human being. He responded that he was a wild goat. When I asked him whether he was a stone, he said that he was the sea." (1)

\section{Yeltsin.}

a. Anecdotes. A I, a34; A I, a35; A II, a6; A IV, a39; A V, a1; A V, a15; B VII, a1.

1. Yeltsin's plane enters a sandstorm. They must make an emergency landing in an unknown place. Soon his baggage is gone. Yeltsin: "Hurrah! Back in the homeland!" (1) Compare with A II, a18.

2. Yeltsin is walking in Moscow. He meets three spirits. The first is the spirit of Nicholas the First, the second the spirit of Alexander the First. Yeltsin asks the third spirit: "Are you the spirit of Peter the First?" - "Are you crazy, I've just come from the night watch." (1) 
3. At a demonstration in Moscow, the people demand milk, meat and bread. Yeltsin brings a case of milk, a conveyer-full of meat and 35 loaves of dry bread to the balcony of the Supreme Soviet building. Now the people of Moscow are satisfied. (1)

\section{Chernenko.}

\section{a. Anecdotes.}

1. At Andropov's funeral, Chernenko let his hand, raised in salute, suddenly fall. Was he really that weak? - "No, he was gesturing that Andropov must be dropped lower into the ground." (1)

b. Conundrums. A VIII, b1.

\section{Andropov.}

a. Anekdoodid. A I, a21; A IV, a39; A VII, a1.

b. Conundrums. A I, b19.

1. Why were Andropov and Chernenko elected to the Politburo unanimously? - Andropov had the worst kidneys and Chernenko had the worst cardiogram. (1)

2. What is the shortest anecdote? - Andropov, because there are no anecdotes about him. (1)

\section{Kosygin.}

a. Anecdotes. A IV, a52.

1. The BBC knows all the secrets of the Soviet Union. At a session of the Politburo, members are not permitted to leave the room. A cleaning lady announces: "The BBC says that Kosygin has wetted his pants." (1)

\section{Sobchak.}

\section{a. Anecdotes.}

1. At the Second Congress of People's Deputies: "Whoever's for communism, sit on the left. Whoever's for capitalism, sit on the right." Sobchak: "I'm all for communism, but I'd like to live like a capitalist." - "Then come work at the presidium!" (1) Compare with A I, a5.

\section{Yazhov.}

\section{a. Anecdotes.}

1. What strange sign is that on the side of that plane? - "That's Dmitri Yazhov looking out the window!" (1)

XII Krupskaya. A I, a23; A II, a7; A I, b3.

XIII Dzerzhinsky. A I, a5; A I, a23.

XIV Beria. A I, a3; A II, a8.

XV Bulganin. A I, a25. 
XVI Zhdanov. A II, a12.

XVII Podgorny. A IV, a52.

XVIII Gretshko. A IV, a47.

XIX Ryzhkov. A IV, a39.

XX Ligachev. A IV, a39.

XXI Zhirinovsky. A I, a11.

XXII Katarina II. A II, a18.

XXIII Kutuzhov. A IV, a47.

\section{GERMANS.}

\section{a. Anecdotes.}

\section{Hitler.}

a. Anecdotes. A I, a31; A II, a2; A II, a11; A II, a13; A IV, a34; A IV, a43; A V, a42.

1. In 1941, Hitler is making a speech at a parade. His soldiers shout: "Fuhrer, we will follow you!" In 1943 Hitler makes a speech to the soldiers on the Eastern front, at the end of which he announces that he is returning home. Soldiers: "Fuhrer, we will follow you!" (1)

2. Hitler tells his doctor that when he was young he was a psychopath. His doctor: "But you're hardly old now!" (1)

3. From a 21 st Century encyclopaedia: "Hitler: a minor tyrant of the Stalinist epoch." (1)

\section{Müller.}

\section{a. Anecdotes.}

1. Stirlitz is walking in the forest. Somebody knocks on a tree. "A woodpecker," thinks Stirlitz. "You're a woodpecker yourself," thinks Müller.

2. Müller and Bormann are at a cafe. M: "Now Stirlitz will come and order a beer and 2 sausages. That's his password. Then we'll arrest him." Stirlitz comes, orders a beer and says: "Forget the sausage," and sticks out his tongue at the others.

3. Stirlitz is walking in the street. Müller thinks: "Interesting, I wonder where he is going?" - "None of your business, dog," thinks S.

4. Müller, driving at $70 \mathrm{~km} / \mathrm{h}$, looks in his rear-view mirror. Stirlitz is running after him, but with an expression on his face as if he were just walking.

5. Müller finds Stirlitz in his office in front of his safe. M: "What are you doing here?" - "Waiting for a tram." M. leaves the room for a moment. When he returns, Stirlitz is gone. M. thinks: "I guess he caught his tram then." 


\section{Marx.}

a. Anecdotes. A I, a8; A II, a20; A IV, a11; B II, a9; B III, a3.

1. "Would you like me to tell you a joke about Marx?" - "If you like, but I don't much like jokes with beards" [in Estonian "jokes with beards" means old jokes - translator]. (1)

b. Conundrums. A I, b13; A I, b17.

1. What did Marx bequeath Germany? - East Germany got "The Communist Manifesto", the western part got "Das Kapital". (1)

XXVII Engels. A I, a8; A IV, a11; B II, a9.

XXVIII Bormann. A XXV, a2.

XXIX Kohl. A V, a20.

\section{AMERICANS.}

\section{Bush.}

a. Anecdotes. A I, a19; A I, a35; A I, a36; A II, a10; A II, a16; A III, a7; A IV, a35; A IV, a36; A IV, a39; A IV, a43; A V, a9; A V, a10; A V, a12; A V, a13; A V, a14; A V, a15; A V, a16; A V, a18; A V, a19; A V, a20; A V, a21; A V, c1; B VII, a1.

b. Conundrums. A V, b1.

1. What is it: Bush has a short one, Schwarznegger a long one, but the Pope doesn't have one at all?

- A last name. (3)

c. Gesture anecdotes. A V, c1.

XXXI Truman. A II, a9.

XXXII Roosevelt. A II, a10.

XXXIII Nixon. A IV, a10; A IV, a36; A IV, a38; A IV, a43.

XXXIV Carter. A IV, a39.

XXXV Vance. A IV, a39.

XXXVI Baker. A IV, a39.

XXXVII Reagan. A I, a35; A II, a10; A III, a7; A IV, a34; A IV, a35; A IV, a36; A IV, a37; A IV, a38; A IV, a39; A IV, a43; A IV, a53; A V, a7; A V, a8; A V, a10; A V, a11; A V, a12; A V, a13; A V, a15; A V, a17; A V, a37; B VII, a10.

XXXVIII Bolivar. A XLII, a2.

\section{OTHER NATIONALITIES.}

\section{Gustav XVI.}

\section{a. Anecdotes.}

1. King Gustav the XVI says to Queen Silvia: "Oh, my first!" Silvia: "Oh, my sixteenth!" (1) 


\section{Allende.}

\section{a. Anecdotes.}

1. There is a party meeting at the factory. The partorg announces that comrade Allende has been killed. An old communist in the back row can't hear and asks the announcement to be repeated. When the old man doesn't hear even after the fifth time, the partorg gets angry: "They killed who they needed to kill, now stop disturbing the meeting!" (1)

\section{Lumumba.}

\section{a. Anecdotes.}

1. A Komsomol functionary is at a banquet in Africa. He is asked whether he likes Lumumba. On hearing the functionary's affirmative answer, the host says: "Have another piece then!" (2)

\section{Napoleon.}

\section{a. Anecdotes.}

1. Fleeing across the Nemen river, Napoleon asks the boatman: "Have you taken many deserters across this river?" - "No, you're the first." (1)

2. Alexander the Great, Caesar/San Martin and Bolivar/Napoleon are watching a military parade in Red Square. Alexander and Caesar think that they would conquer the world with such tanks and planes. Napoleon reads "Pravda" and says: "If I had had a newspaper like this, nobody would have found out that I lost the Battle of Waterloo." (2)

XLIII Mitterand. A V, a19.

XLIV San Martin. A XLII, a2.

XLV Nelson. A VI, a47.

XLVI Churchill. A II, a4; A II, a10.

XLVII Thatcher. A IV, a4.

XVIII Mussolini. A II, a13.

XLIX Ceausescu. A II, a4.

L Kekkonen. A IV, a40.

LI Hannibal. A IV, a47.

LII Alexander the Great. A XLII, a2.

LIII Caesar. A XLII, a2.

LIV Gandhi. A IV, a4.

LV Castro. A III, a4.

LVI Hussein. A IV, a43. 


\section{ESTONIANS.}

\section{Väljas.}

\section{a. Anecdotes.}

1. A man goes to the store, but teverything is sold out. Three men walk by, who introduce themselves: Toome [= "we bring" in Estonian - translator], Väljas [= "outside" in Estonian translator], and Otsasson [= "sold out" in Estonian - translator]. The man thinks - "they're bringing the goods", "the goods are outside", and "already sold out". (also Laosson - the goods are in the warehouse) (19)

2. In Moscow, Väljas/Rüütel complain to Gorbachev that Estonia is short of building materials. Gorbachev: "Ja ponimaju." [= "I don't know" in Russian - translator] Väljas rejoices - Japanese houses are going to be built in Estonia. ["Ja ponimaju" sounds like "Jaapani maju" which means "Japanese houses" in Estonian - translator] (3)

b. Conundrums. A LXI, b1.

\section{Rüütel.}

a. Anecdotes. A I, a34; A LVII, a2; B VII, a1.

1. Rüütel visits a school. The children have been taught to say that their mother is Nôukogu [= "Soviet", although this word has a wider meaning in Estonian than in English, and hence it can also mean "organisation" or the administrative organ of an organisation - translator] and their father Rüütel. Rüütel asks Juku: "And who would you like to be when you grow up?" Juku: "I won't have to become somebody, with parents like that." (1)

\section{Savisaar.}

a. Anecdotes. B VII, a10.

1. One woman is complaining to another that she hasn't seen meat or eggs for a long time. - "Go to the sauna with Savisaar and you'll see both." (2) Compare with B I, b16.

2. Ülo wants to go swimming at the "Dünamo" swimming pool. Mati: "The pool's closed, they're developing Savisaar's picture there." (1) Compare with A IV, b6.

3. A man shouts to his wife that he can see a woman who is in love with Savisaar. His wife rushes to the window: "But that's Savisaar's wife." The man: "Of course it is, does that surprise you?" (1)

4. Farmers complain: "We've already resorted to eating hay, soon we'll be neighing too." Savisaar: "Meri and I eat ham and honey, but we neither howl like wolves nor buzz like bees." (1)

5. In a cafe, Savisaar and Lauristin order two ice-creams, teo coffees and four sandwiches. Lauristin: "But where are the sandwiches?" The waitress: "I can't bring you sandwiches, you two are two thin." (1) 


\section{Käbin.}

\section{a. Anecdotes.}

1. The first secretary of the Central Committee [of the ESSR - translator] Käbin spoke Estonian badly. Once he began a speech with the words: "Dear zebras [the word in Estonian was "sebrad" which sounds like "sôbrad" (friends) and also means zebras - translator] and war veterinarians!" (1)

2. Käbin at an agricultural congress: "Corn needs shit and warmth to grow." A tractor driver: "The right place for it is up your ass, there's both shit and warmth in there!" (1)

\section{Vaino.}

a. Anecdotes. A IV, a39.

1. A phone rings at Vaino's secretary's desk. The caller asks for comrade Makulin three times. In the end Vaino/Lebedev picks up the phone: "Ma kulin." [this is intended to show how bad Vaino's Estonian was - it is correct to say "Ma kuulen" (literally "I hear you") when one answers the telephone - translator] (2)

\section{b. Conundrums.}

1. What is Karl Vaino doing at the Kremlin? - He's there to see if Väljas [also means "outside" in Estonian - translator] is cold [i.e. dead - translator]. (3)

\section{Tônurist.}

\section{a. Anecdotes.}

1. Edgar Tônurist writes home from Moscow to his wife, requesting that she buy him books. His wife in the bookstore: "I'll have those two shelves there, please." (1)

\section{Mäe.}

\section{a. Anecdotes.}

1. One woman asks another woman why there are no longer request concerts on the radio. The other woman answers: "The people would like Litzman and Mäe to sing a duet to the tune of "Hakkame mehed minema, kodu poole kôndima."" [= "Let's start to go, men, walking homewards" - translator] (1)

\section{Aasmäe.}

\section{b. Conundrums.}

1. What does Aassmäe's city government represent, through the three lions on the flag of the city of Tallinn? - The first lion embodies prostitution, the second corruption and the third speculation. (1)

LXV Litzman. A LXIII, a1.

LXVI Kingissepp. A I, b2.

LXVII Toome. A LVII, a1. 
LXVIII Otsasson. A LVII, a1.

LXIX Laosson. A LVII, a1.

LXX Lebedev. A LXI, a1.

LXXI Lauristin. A LIX, a5.

LXXII Meri. A LIX, a4.

\section{B. NATIONALITIES}

\section{Russians.}

1. God to the apes: "Climb down from your trees and become human beings." God asks one ape why he won't come down. The ape: "Chievo?" [= "What?" in Russian - translator] (1)

2. On the moon, the Americans spotted hairy creatures without socks or underpants. Boss: "Then the Russians have made it to the moon." (1)

3. A wise man gives another man a wind-up cockroach to ward off the same pests. Soon the man visits the wise man again, although this time he asks for a wind-up Russian. (1)

4. A Russian and an Englishman are flying in a plane. The Englishman: "You already have televisions in cow barns." The Russian: "Those are our houses." (2)

5. A Frenchman is asked: "How do you get to work?" - "I drive my car." - "But how do you go abroad?" - "By plane." A Russian is asked: "How do you get to work?" - "By bus." - "But how do you go abroad?" - "By tank." (6)

6. A Japanese explains to a Russian how workers there work 1 hour for themselves, 1 hour for the company and 6 hours for Japan. The Russian worker is ready to work 1 hour for himself and 1 hour for the company, but he can't understand why he should work for Japan. (3)

7. The Japanese give the Russians a robot with which, in Japan, two people work. In Russia 3000 people work with the same robot, but the Russian lies and says that three people work with it. The Japanese man can't get any sleep: "What on earth could the third one possibly do?" (2)

8. An old man from Hiiumaa says to his wife: "The Russians went to the moon." - "You mean all of them?" (1)

9. A drunken Russian: "All Estonians belong in coffins!" An old lady: "But there are good Estonians too." - "Then good Estonians in good coffins!" (1)

10. A Russian complains, "Half of the people in our building are Estonians." Another Russian sighs: "I know, they're everywhere!" (1)

11. In Tallinn, a Russian asks for directions from an Estonian. The Estonian looks at the address: "Go straight, then a little to the right, then a little to the left and then you'll find yourself right in front of the train station." (1)

12. Petka goes to Estonia. Two years later Chapayev goes to see what happened to Petka. C. finds Petka fishing by the banks of the Narva river. He shouts to Chapayev: "Damn Russian, what do you want?!" (2)

13. A friend said: "I just came from the beach. There were few people but lots of Russians." (1) 
b. Conundrums. A III, b2; B VI, b4.

1. What is the difference between Sputnik and a Russian? Sputnik is a satellite of the earth, but a Russian is a fellow countryman. [this is a pun - "satellite of the earth" in Estonian is "maa kaaslane" and fellow countryman is "kaasmaalane" - translator] (24)

2. What is the difference between a Russian and an Earth satellite? - An Earth satellite revolves around the Earth, but a Russian revolves around Tallinn. (1)

3. Is a Russian a brother or a friend? - A brother, because one can choose one's friends. (4)

4. Why do Russians wear felt footwear? - To sneak quietly past Americans. (23)

5. Why don't the Russians pass the Americans? - They don't want the Americans to see their bare bottoms. (4)

6. What is the difference between Americans and Russians? The Americans went to the moon and came back, but Russians crossed the Peipsi river and never came back. (1)

7. Why do the Americans/Chinese/Mongolians build round houses? - So that Russians can't hide behind every corner. (5)

8. What is it am I describing? It has 50 heads, belly to back and back to belly. When it stands still, it stinks, when it moves, it shouts? - Hungry Russian soldiers. (1)

9. How do women in different countries keep their men? A German woman with her diligence, a French woman with her body, but a Russian woman by threatening him with the Party. (1)

10. What nationality were Adam and Eve? - Russian. Because they had only one apple to eat between the two of them, they went around naked and shouted that they live in paradise. (4)

11. Was the love-god Amor Greek or Italian? He was Russian, since he had bare buttocks and a weapon in his hand. (1)

12. What people invented love? - Russians, because it's something one doesn't have to pay for. (1)

13. What happens when a Russian climbs a tree? - One less Russian/fool on earth. (2)

14. When a Russian is chopping down a tree, which strike is the one which brings the tree down? The last one. (1)

15. Why don't Russians wear hats? - Sawdust doesn't catch cold. (2)

16. Why do Finnish men go to the Russian border showing off their naked bodies? - So that Russians can see eggs [= "balls" (vulgar) in English - translator] and meat. (2) Compare with A LIX, a1.

17. How is it possible that a Russian bought caviar and died? - He spent his month's wage on the tin of caviar. (1)

18. What is Russian business? To steal a case of vodka, sell it, and spend the money earned on drink. (4)

19. Who invented the x-ray? - A Russian serf called Ivan Pushkov in the 16th Century. He apparently said to his wife: "I can see right through you, you whore!" (1)

20. How can you get 25 Russians into a phone booth? - Throw in a dollar bill. (1)

21. How many train cars would it take to deport all the Russians [from Estonia - translator]? - Four carriages of ashes. (1) 
22. What is a Chinaman? - A Russian who has gone yellow waiting for Communism. (29)

23. What is the difference between giving a knife to an Estonian and to a Russian? - One gives the handle end to an Estonian but the blade end to a Russian. (1)

24. What is the difference between an Estonian and a Russian? - An Estonian talks with his mouth and works with his hands. A Russian talks with his hands and works with his mouth. (1)

25. What are the most common animals in Estonia? - Russians. (1)

26. What is there no shortage of in Estonia? - Russians. (4)

27. Why do Russians/Soviets have a long life expectancy? He who suffers will live a long life. (22)

\section{Chukchis.}

a. Anecdotes. A I, a21; B III, a8.

1. Brezhnev died. The collective farm sent a Chukchi to Brezhnev's funeral in Moscow. Once home he says: "I couldn't find a wreath or a flower basket, so I brought a cake. When the music began, I was the first to ask the widow to dance." (1) Compare with A IV, a8.

2. A Chukchi/Eskimo wants to buy a good which is in short supply/gasoline. He is led to the queue for the mausoleum - that's the longest queue. The Chukchi: "When my turn came, the salesperson was already dead." (2)

3. Brezhnev gives a Chukchi a "Buran". The Chukchi: "It's a good machine, but the dogs aren't able to pull it." (1) (a "Buran" is a skidoo)

4. A Chukchi shouts towards America: "Beggars! You bought Alaska, but you didn't have enough money to buy Chukchiland!" (3)

5. Russian oil researchers are in Chukotka. A Russian gets lost ans shouts: "Hey you people!" A Chukchi: "Now we're people, but when I go to Moscow, then you say: "Look, a Chukchi!"" (1)

6. Ten Chukchis declare war on America. The Americans: "There are several hundred million of us." - "Gosh, where will we bury you all!" (1)

7. A Chukchi returns from a congress in Moscow. "They said "Druzhba this, Druzhba that", I guess there's going to be a lot of cutting down of trees in the near future." (3) ("Druzhba" is a brand of chainsaw) ["Druzhba" means "friendship" in Russian - translator]

8. Some Chukchis/Chinese decide to push the Kremlin to Chukchiland. They put their bags down and push. A Chukchi: "We've pushed so much that we can't even see our bags any more." (2)

9. A Chukchi returns from Moscow: "First thing - Lenin and Uljanov (or Brezhnev) are one person, second - Marx and Engels are two different people and third - Slava Ka-Pe-Es-Es isn't a person's name at all!" ["Slava" means "honour" in Russian, and K.P.S.S. are the Russian initials for "Communist Party of the Soviet Union" - translator] (2)

10. A Chukchi visited America: "Life is just like at home - for a dollar you can buy anything, but a ruble is good for nothing!" (1)

11. A Chukchi was asked about other nationalities. He knew only Chukchis. - "But Estonians?" The Chukchi: "Estonians are cannibals. No-one who has gone to Estonia has ever returned." (1) 


\section{b. Conundrums.}

1. What does a Chukchi do when the borders are opened? - He climbs a tree. Firstly to see who is stupid enough to come and live here, and secondly so that those leaving would not wear the road away. (2)

\section{Jews.}

a. Anecdotes. A IV, a22; A IV, a25.

1. A Jew takes a picture of Lenin to Israel. At the Soviet border he says that it is a picture of Lenin. At the Israeli border he says that it is a gold picture frame. (2)

2. A Jew works in the Kremlin. He sits in the Spasski tower and announces the approach of communism. The Americans offer him a job predicting economic crises. - "No thanks, I need fulltime work!" (1)

3. The sculptor Kerbel has made a monument to Marx in Sverdlov's square. Commentary: "Threefold arrogance. One Jew has made a statue of another Jew in a square named after yet a third Jew." (1)

4. A Jew has a set of one thousand pictures of Politburo members, since he wants to open a shooting range in Israel. (1)

5. A Jew reads newspapers assiduously in order to find out how good life is here. (1)

6. A Jew works in a baby carriage factory. He wants to make a carriage for himself too, but no matter how he assembles the parts he gets a machine gun. (1)

7. A Jew phones the KGB: "My friend has guns buried in his garden and gold hidden in his wood pile." Then he phones his friend to tell him to expect some men to come and split his wood for him and dig in his garden. He wants a fur hat in return. (3)

8. "Rabinovich, have you joined [in Estonian the word "astuma" (to join) means both to join an organisation and to step in something (in this case dog excrement) - translator] the party?" "Where?" says the Jew/Chukchi and inspects the bottoms of his shoes. (3)

9. A Jew phoned Chapayev and asked him whether the Jews really sold Russia out. Chapayev confirms this. In that case, the Jew says, he wants to get his land back. (1)

10. A man frequently receives packages from a Jew he hid from the Communist authorities. A friend: "Haven't you thought about your future?" - "Yes indeed, now I'm hiding a Japanese!" (1)

b. Conundrums. A II, b2; B VI, b4.

1. How does a smart Jew speak to a stupid Jew? - Haughtily and from New York. (1)

2. Why isn't there a representative of New-Guinea in the Comintern? - There was no Jew willing to put a ring through his nose. (1) 


\section{The Chinese.}

a. Anecdotes. B II, a8.

1. A rocket was launched in China which carried 5 cosmonauts and 500 engine-stokers. (1)

2. At the end of a Sino-Russian joint space flight the Chinese pilot had a blue hand, since the Russian had held onto his hand the whole time and threatened: "Don't you dare touch anything!" (1)

b. Conundrums. A II, b2; B I, b22.

1. Why do the Chinese eat with chopsticks? - If they ate with spoons, knives and forks, they would eat Russia bare. (13)

\section{Estonians.}

a. Anecdotes. A V, a28; B I, a8; B I, a9; B I, a10; B I, a11; B II, a11.

b. Conundrums. B I, b23; B I, b24; B IV, b4.

1. Why did the Estonian put on a gas mask when a nuclear bomb landed on Moscow? - To hide his smile. (1)

\section{Other nationalities.}

\section{a. Anecdotes.}

1. A Czech caught a goldfish. He wishes three times that China attack Czechoslovakia, because in doing so the Chinese would have to pass over Russia six times. (1)

2. The Prime Minister of Finland goes hunting in Africa and shoots a giraffe and 12 notmes. His secretary then goes to Africa to find out what a notme is. A black man jumps out from behind a bush and shouts: "Not me!" The Prime Minister shoots. (1)

3. The Finnish Prime Minister returns from Moscow and announces that there is a shortage of mouse oil in Russia. There was a line-up several kilometers long outside a building with the sign "MAUS OLEUM". (1)

\section{b. Conundrums.}

1. How do Czechs know that the world is round? - In the autumn of 1945 they beat one occupation army back westwards, but in 1968 the occupants returned, this time from the east. (1)

2. What would happen if a nuclear bomb landed on Poland? - Captain Kloss would survive. (3) (Captain Kloss is a Polish spy in the film "There's more at stake than life".)

3. What's black on the outside and red on the inside? - A black communist. (1)

4. What is one Englishman? - Shakespeare. Two Englishmen? - A bet. Three Englishmen? Parliament. What is one Frenchman? - A drunk. Two Frenchmen? - A business deal. Three Frenchmen? - The French Revolution. What is one Jew? - A scholar. Two Jews? - A chess game. Three Jews? - A conference. What is one Russian? - Dumb-Ivan. Two Russians? - A line-up. Three Russians? - The brainless masses. What is one Estonian? - Meie Mats. [the name of an annual 
humour competition in Estonia - translator] Two Estonians? - The Supreme Council. Three Estonians? - A Song Festival. (1)

\section{Three-nationality anecdotes.}

a. Anecdotes. A I, a19.

1. An Estonian/Rüütel, Russian/Yeltsin and a German/Bush are flying in an aeroplane. The German throws a pack of "Marlboro" cigarettes out of the plane, and the Russian a bottle of vodka - they have enough of these things. The Estonian throws the Russian out of the plane, because there are enough of them in Estonia. (157)

2. The representatives of several nationalities are flying in a plane. Three of them must jump out of the plane, or else the plane will drop to the ground. Two jump out praising their homelands, but the Lithuanian throws the Russian out of the planeand says: "Long live a free Lithuania!" (3)

3. The representatives of three nationalities must jump out of a doomed plane. There are only enough parachutes for two of them, so the Russian is given a backpack. (4)

4. An Estonian, a Russian and a German are in prison. Gorbachev promises to release the prisoner who build the best toilet. The Estonian wins - it's musical (the door creaks) and fold-up (it falls apart). (2)

5. The representatives of three nationalities are in prison. Gorbachev promises to free the prisoner who crosses the bog/bridge with nails sticking up. The Estonian drives a "Zaporozhets"/road roller and thereby earns his freedom. (2)

6. An American, an Englishman and a Russian are teaching a cat to eat mustard. The first forces the cat to eat the mustard, the second tricks the cat, but the Russian covers the cat's bottom with mustard. The cat licks it and squeals. The Russian: "He's eating it willingly and he's singing too!" (1)

7. A French woman and her daughter, an Englishman and a Russian are sitting together in a train. While the train passes through a tunnel, one can hear the sound of kissing and the boxing of ears. Both of the French women suspect that the other was kissed and the Russian complains that he was needlessly hit. The Englishman: "That was a good one, kissing my own hand and hitting the Russian in the head!" (1)

8. A Jew, a German and a Russian are flying in a plane. God promises to great each one his wish. The German requests that there be no Russians on earth, and the Russian that there be no Germans on earth. The satisfied Jew asks for a cup of coffee. (1)

9. The representatives of different nationalities are prisoners on an island of cannibals. They will be released if they name something that the cannibals don't have. The Frenchman suggests girls, the Englishman genuine punch, the Russian the Politburo. The cannibals free the Russian. (1)

10. An Estonian, a German and a Russian (or Gorbachev, Brezhnev, Reagan) throw a machine, a tank and a bomb out of a plane. In Germany and Russian all the people are crying, but in Estonia all are laughing, because Savisaar/Juku farted so powerfully that half of Toompea/the toilet blew up. (3) 


\section{ANIMALS.}

\section{Rabbit.}

a. Anecdotes. A IV, a9.

1. A rabbit repeatedly asks for carrots from a store, until the salesman gets fed up and nails him to the wall by the ears. The rabbit sees Lenin's/Stalin's/Brezhnev's/Gorbachev's picture on the wall opposite him and asks: "Did he ask for carrots too?" (50)

2. Rabbit tells bear that because of his shortsightedness he wasn't accepted into the army. Rabbit: "Can you see that fir tree over there?" - "Yes, I can." - "Well, I can't!" (35)

3. Because he is crossed-eyed, rabbit wasn't accepted into the army. Bear asks rabbit to knock his teeth out so that he wouldn't be accepted into the army, but it turned out that he was not accepted because of his flat feet. (3)

4. Rabbit and bear are called up by the army. Rabbit recognises the sneakers and is sent to the infantry. Bear, after having been instucted by rabbit, recognises the sneakers even before they are shown to him, so he is sent into espionage. (3)

5. Rabbit runs through the forest holding on to his bottom: "Today is Lenin's birthday and the Russians stick a red flag in every hole." (8)

6. The animals have a day of voluntary weekend work. Rabbit sits on a stump and whistles: "I whistle on your voluntary work." [In Estonian to "whistle on" something means to not care a damn about it - translator]

7. A rabbit meets a wolf who wants to eat him. Rabbit: "Do you have a ration card for meat?" (10)

8. A rabbit, a squirrel and a St. Bernard are in prison - the rabbit for stealing cabbage from the fields of the collective farm, the squirrel for stealing nuts from the state forest. The St. Bernard got 25 years for biting a pioneer's bottom. (the biter can also be a little boy.) (2)

\section{b. Conundrums.}

1. What is the difference between a rabbit and a propagandist? - A rabbit doesn't babble. (3) Compare with D I, b28.

II Parrot. A IV, a52; A V, a42; A V, a43; D II, a3; D III, a5.

\section{Other animals.}

\section{a. Anecdotes.}

1. A fox sees a little cake in the forest and says that he will eat it. - I'm not a little cake, I'm a Chernobyl porcupine." (1)

2. An ant and an elephant want to cross the border. The elephant has no documents, so the ant hides him between two pieces of bread. A: "It's none of your business what I have in my sandwich!" (29)

3. An English greyhound asks a Russian mongrel whether life has got better thanks to perestroika. The mongrel: "The food dish has been pushed farther away, but my leash has been extended and now one can bark as much as one wants." (2) 
4. A dog: "How does the food program work?" - A fox: "I eat the chicken and you chew on the bones." (1)

5. A crow is sitting in a tree. He tells the other animals that he is sitting there doing nothing, just vegetating. A herd of other animals come to vegetate under the tree too. A hunter shoots them all. The crow: "One can only vegetate in high places." (1)

6. Some forest animals want to build a bridge. Fox and bear return from Moscow without any materials. Donkey receives materials from Moscow and says: "They're all like me there." [in Estonia the donkey's main attribute is considered to be stupidity, instead of stubbornness translator] (1)

7. A musical outhouse is built in the forest. Bach is played for Bear, heavy metal for Rabbit, but Wolf leaves the outhouse unhappy and wet - he was played the anthem [i.e. he had to stand, which prevented him from being able to do his business - translator]. (14)

\section{b. Conundrums.}

1. Can bedbugs start a revolution / go on strike? - Yes, since in them flows the blood of the working people. (1)

2. Can one kill a bedbug? - No, since the blood of the working people flows in its veins.

3. Can one sit on a porcupine with one's bare bottom? - One can: 1. If the bottom is not your own. 2. If the porcupine is fat. 3. If the Party and the government order you to. (1)

4. What is power underneath and feathers on top? - A sparrow/crow on the roof of the Kremlin. (5)

5. What is a lizard? - A crocodile who has survived communism/the revolution/returned from BAM. [see anecdote A IV, a43 (Brezhnev anecdote 43) - translator] (26)

6. What is a crocodile? - A lizard which has gone undergone capitalism. (2)

7. What is a crocodile? - A lizard that sucked up to [i.e. joined - translator] the Party. (15)

\section{THE SOCIALIST AND COMMUNIST SYSTEM.}

\section{Communism. The Communist Party.}

a. Anecdotes. B III, a8.

1. A lecturer/Brezhnev explains that we are standing with one leg in communism and one in socialism. A little old lady asks: "How long are we going to stand astride like that?" (3)

2. Petka reads from a history book: "The patricians called upon hetaerae and had an orgy." Chapayev explains that "patricians" is a misprint and should be "Party members". (1)

3. A lawyer, a surgeon, a construction worker and a communist are arguing whose profession is the oldest. The communist wins, because before there was anything there was chaos, but chaos was created by the communists. (1)

4. There is a slogan in the office of the First Secretary of the Party: "Our party fights in the name of being named communist!" (1)

5. The director of an organisation is asked why he wasn't at the last meeting of the Party. - "If I'd known that it was going to be the last, I would have come for sure." (2) 
6. The machine gun stops firing. - "Commander, I've run out of bullets!" - "Are you a Communist or not!" - The machine gun begins to rattle even more noisily than before. (3)

7. A group of women are boasting about how important their husbands are. One woman: "But my husband works in the Comintern as a Chinaman!" (1)

8. A man finds his wife in bed with her lover: "If I wasn't a member of the Party, I'd break your bones!" His wife: "Long live the CPSU!" (1)

9. A collective farmer is arguing with his wife: "I'll shame you and join the Party!" (1)

10. A Comsomol functionary visits a brothel. There is a bit of a misunderstanding, since he wants to pay for the prostitute's services by money transfer. (1)

11. A potato, a radish, a cucumber and a flea wish to join the Communist party. Only the flea was accepted, since proletarian blood flows in his veins. (1)

12. An alcoholic sees a donkey at the zoo. He kisses it and says: "Poor rabbit, what have the Communists done to you?" (1)

13. A girl tells her school teacher that her cat had kittens and that they were all Communists. Two weeks later the girl announces: "They're not Communists anymore, they have opened their eyes."

14. Juku has joined the pioneers, and since pioneers always tell the truth, he admits that he ate the jam and shitted in the jars. Grandpa to grandma: "I told you that it was shit, but you said there wasn't enough sugar." (1)

15. Little Red Riding Hood is walking in the forest. All of a sudden she realises that her underpants are gone. Soon her pants return, with a little note: "I washed your panties. Timur." [Timur was a little boy who was raised to hero status in recognition of his devotion in helping old people and others who needed help - translator] (7)

16. A wolf/Ali Baba and the 40 thieves rape Little Red Riding Hood. Little Red Riding Hood doesn't dare go home, and so sleeps in the forest. In the morning she finds a note which says: "You're a virgin again. Timur and his team." (4)

\section{b. Conundrums.}

1. What is communism? - Your wife doesn't belong to you, she belongs to the state. (1)

2. What is a line-up? - The communist approach to the counter. (5)

3. Why isn't soap available any more? - The Communists are trying to clean themselves. [i.e. of guilt -translator] (2)

4. What is a wiener? - A thick frankfurter sausage which has survived communism/the revolution. [a "sardell" (frankfurter sausage) is bigger than a "viiner" (wiener) - translator] (11)

5. Can one order goods by phone in a Communist society? - Yes, but the goods are delivered by television. (2)

6. Why is there no meat in Russia? - Because Communism is moving ahead so fast that animals can't keep up with it. (1)

7. What kind of women are loved in a Communist society? - Plump ones, since men aren't dogs, that run after bones. (1) 
8. Is there love in a Communist society? - No money, no love. (6)

9. Were there robberies in Communist societies? - No, there was nothing to steal. (2)

10. Does the newspaper exist in a Communist society? - Yes, that's where we read how well we live. (3)

11. Does vodka exist in a Communist society? - No, and the snack ["sakuska" = the snack one eats with vodka in Russia - translator] no longer exists either. (1)

12. What is the shortest anecdote? - Communism. (1)

13. What is the horizon? - It is like Communism, the closer you go to it, the farther away it gets. (1)

14. Will Communism come to Armenia? - No, because Communism isn't behind the mountains [an expression meaning "far away" in Estonian - translator], but Armenia is. (1)

15. What would you get if you incorporated Bulgaria into the Soviet Union? - Nothing, not even tomatoes. [tomatoes are one of Bulgaria's main agricultural products - translator] (2)

16. What would happen if socialism came to Cuba? - Then Cuba would begin to import sugar. (2)

17. What would happen if one began to build socialism in the Sahara? - There would soon be a shortage of sand. (4)

18. Would it be possible to make Monaco into a socialist state? - So much chaos couldn't be fit into such a small country. (1)

19. Would it be possible to make Sweden into a Communist country? - It would, but it would be an awful shame. (1)

20. In the sauna, how can one distinguish between the director, the worker and the Communist? The worker has calloused hands, the director has a big belly but the Communist has a blue chest from beating his chest and saying "I am a real Communist!" (1)

21. Three German warplanes and one Russian warplanes are flying in the sky. Who will win? - The Russian, because he is a Communist. (1)

22. Pitch-patch? [an abbreviated form of a riddle which continues: "without a stitch, what is it?" translator] - A Communist's pants. (1)

23. What is another name for a winter coat? [in Russian "puhvaika" - translator] - The party jacket.

24. Of what profession are most members of the Communist party? - They are mostly railway engineers. They learned their trade on the steam trains, and then went to work at the party because their work was dirty. The steam trains disappeared but they stayed on at the party. (1)

25. What is the longest anecdote? - The party constitution. (4)

26. What is pluralism? - That is when the the opinion of the president of the Soviet Union doesn't match that of the Supreme Soviet. (1)

27. Are there poor people in the Soviet Union? - Yes there are, those are people whose apartment, country house and car all belong to the state. (1)

28. What is the difference between power and a propagandist? - Power doesn't like to chatter. (1) Compare with C I, b1. 
29. What is the difference between an agitator and a shaver? - One earns a living with the help of his own chin, the other with the help of others' chins. (1)

30. What do you get when you combine a duck ["part" in Estonian - translator] and a squirrel ["orav" in Estonian - translator]? A partorg [Communist party organiser in Russian - translator]. (1)

31. Guess what I'm describing - 40 teeth and 4 legs? - A crocodile. Guess what I'm describing - 4 teeth and 40 legs? - The Politburo. (3)

32. Who was the greatest communist? - Toots, since he painted the world red. (2)

33. Why are the streets of Tallinn being excavated? - They're looking for Kalevipoeg's party membership card. (45)

34. What did Heli Lääts sing at the last party congress? - "The circus will never die". (1)

35. Who is a pioneer? - A stupid person with a red handkerchief. (1)

36. What is the difference between a pioneer and a hamburger/perogie/egg? - A pioneer is always prepared, but one must cook a hamburger first. (45) (A pioneer is always ready - reference to the pioneer's slogan "Always ready!")

\section{KGB, Army and Police.}

a. Anecdotes. A IV, a35; B III, a7; C I, a2; C I, a3; C I, a4.

1. Teacher: "Pille, name me the explosive consonants!" - "KGB." (1)

2. The phones rings at the KGB. "Is that the KGB?" - "The KGB building burnt down." The third time: "I told you that the KGB building burnt down!" - "Yes, I know, but it's so nice to hear." (2) Compare with A I, a33.

3. A man informs the KGB that his parrot has flown away. - "Why should that concern us?" - I just wanted to say that I don't understand his political opinions." (1)

4. The phone rings at the KGB. A woman's voice asks the time. A minute later she phones again. This continues for an hour. Finally the official answers: "Comrade Filimonova, we will return you your alarm clock." (1)

5. The phoe rings at the KGB: "My neighbour is eating red caviar. Find out where he got it." Ten years later: "My neighbour is eating sausage. Find out where he got it." Twenty years later: "My neighbour is eating something. Find out where he got it." (2)

6. A sign on the door of the security police: "Wet paint. Knock [in Estonian to knock also means, in slang, to inform - translator] by phone." (1)

7. Specialists from all over the world travel to Egypt to research the identity of a mummy that had been found in an ancient grave. Two KGB men from Moscow go as well. After two hours of investigation they declare: "He finally confessed. He is Ramses XII." (3)

8. Petka returns from an NKVD course and Chapayev is curious to find out what he learned there. Petka puts Chapayev's hand in a meat grinder and forces him to confess that he is a member of the White Guard. Having obtained the confession, Petka begins to crank with renewed vigour: "Ah, just as I thought!" (1) 
9. An American spy is sent to work in a Soviet factory. He is told to go to a kolkhoz. The spy doesn't know what a kolkhoz is and decided to give himself up. The KGB official's response: "Get out of my office! Every day I get told that very same story, as a reason for leaving the kolkhoz!" (1)

10. A conscript comes to the medical inspection wearing a sign which says: "I can't speak." The army doctor hits the boy on the thumb with a hammer. The conscript: "A!" - The doctor: "Tomorrow we'll learn to say the letter "B"." (1)

11. A young man doesn't want to join the army, so he pretends that he is short-sighted. The army doctor exempts him from military service. That evening the boy meets the doctor at the movie theater. The young man asks the doctor: "Is that train going to Riga?" (1)

12. On the way to Afghanistan, it is explained to young soldiers that they will receive 100 dollars/rubles for every enemy head. The plane lands. Soon the soldiers all return carrying slit-eyed heads. Their captain: "Fools! That was a stopover in Kirghizia!" (2)

13. During the Afghan war, some soldiers are sent to a new assignment. The helicopter pilot doesn't dare fly low enough that the new men dare jump to the ground, because then the men already on the ground would jump aboard. (1)

14. A German soldier has "Got mis uns" written on his belt buckle. A Chinese boy: "But the Russians and Americans are with us!" (1)

15. A lieutenant asks his wife whether love is work or pleasure. His wife: "If it were work, you'd send a detachment of soldiers here." (1)

16. In the army, an Estonian is given an assignment: to land by parachute and deliver a letter to another division by bicycle. The parachute fails to open: "Russian bullshit once again. There certainly won't be a bicycle there either." (1)

17. One man wants to tell another a subversive joke. - "Don't tell me, I'm a policeman." - "I'll tell it very slowly and many times." (5)

18. A lump of shit floating in the river shouts to a policeman: "Hi colleague! As you know, we're both from the internal organs." (2)

19. A home help robot is invented. But the robot wants to work in high places. When its memory is decreased to the lowest possible, it becomes a policeman. (1)

20. Some policemen find a body in front of a theatre. But since they aren't sure whether theatre is spelled with one or two "a"s, they decide to carry it to the cinema. (4)

21. A little boy makes a policeman out of shit and clay. The next day he didn't make a policeman, because he had too little shit left. (2)

22. A policeman is asked the difference between a donkey and a policeman. The policeman angrily: "Well, what is the difference?" The startled joke-teller: "There is no difference." (2)

\section{b. Conundrums. C III, b4.}

1. How can you recognise a Russian spy drinking tea? - 1. He drinks his tea with the spoon in the cup; 2 . Every time he lifts the cup to his mouth he squints one eye shut. (1)

2. How can you recognise a Russian spy in German territory? - The Russian washes his clothes under the tap, but the German washes his clothes in a basin. (1)

3. What clanks, rattles, hobbles and wails? - A war veteran. (30) 
4. What is the result when one crosses a cow and a silver fox? - An officer's wife. (3)

5. What will World War Three be like? - Who knows, but the fourth will be with sticks. (7)

6. Is there going to be a war? - No, but there will be such a battle for peace that not a single stone will remain standing. (2)

7. How many victories [the meaning of the word "vôit" (victory) is played upon in this joke "vôitu", when added to the end of a word means "quite", hence külmavôitu means "quite cold", for example - translator] did the Russians achieve in World War Two? - Three: In the north quite cold, in the south quite hot, and altogether quite shitty. (1)

8. What are the three great Russian victories? - Quite expensive, quite little and quite shitty [see explanation of preceding anecdote - translator]. (7)

9. Why do policemen go everywhere in pairs? - So that between the two of them they could put together a high school education. (3)

10. Why does the policeman smile at dawn? - He thinks that he's being photographed.

11. What do a policeman and a lump of shit have in common? - They are both from the organs [i.e. of the state, in contrast to the internal organs of the body - translator]. Compare with D II, a18.

12. What is the difference between a policeman and a donkey? - Nothing. Compare with D II, a22.

13. What is it - power lying down, water running? - A policeman being given an enema.

14. What is the terror of the waters? - A policeman in a bathtub. Compare with A V, b3.

15. From what roof can one see the farthest? - Climb up onto the roof of the police station and you'll soon see Siberia.

\section{Politics. Economics.}

\section{a. Anecdotes.}

1. A newspaper salesman shouts: We're all out of "Pravda" ["truth" in Russian -translator], "Sovetskaja Rossiija" ["Soviet Russia" in Russian - tanslator] is sold out. All that's left is "Trud" ["work" in Russian - translator] for 20 kopecks. (1)

2. "Vremja" [a television news program in Russia - translator] begins with a mourning frame and the announcer says: "Dear comrades, you will probably begin to laugh, but we have once again suffered a great loss." (1)

3. The prime minister is flying in a fighter plane, the seat of which catapults in an emergency. The prime minister: "But if the mechanism fails?" - "Then there will simply be new elections." (1)

4. A Soviet hammer thrower has set a new world record. The athlete to journalists: "If the hammer had been accompied by a sickle, I would have thrown it even farther." (1)

5. A man is arrested because his parrot said "Down with the government!" Before the trial the man exchanges his parrot with the pastor's. The prosecutor tries to make the parrot say "Down with the governement!" on its own and then in chorus with the onlookers. The parrot: "Thy will be done!"

6. A Russian ambassador, meeting with aboriginals around a camp-fire, promises that new houses and factories will be built for them. The aboriginals shout: "Nabakabuku!" At the end of the lecture the ambassador and the chief must piss the fire out. The chief is surprised: "Such a big man and such a small nabakabuku." (1) 
7. Having forgotten to take into account the time difference between Rome and Moscow, Moscow radio announces an assassination before it is committed. (1)

8. The Czechoslovakian government asks Moscow for permission to create a Ministry of Oceans. "But you don't have any sea around you?!" - "But why do you have a Ministry of Culture then?" (2)

9. In China some Americans ask: "Whose pie is this?" - "The state's, we have no private property." (2)

10. A Pole is worried about the money he has in the bank. An official reassures the man that if the bank goes bankrupt then the state will compensate the bank's clients, and if the state goes bankrupt then the Soviet Union will compensate. - "But if the Soviet Union collapses?" - "That sight would be well worth two weeks' wages!" (2)

11. A plumber is in prison because while checking the pipes of the Central Committee of the Communist Party he recommended changing the whole system. (1)

12. A man is is prison because he looked at the Kremlin through binoculars. They were apparently rifle binoculars. (1)

13. "Estonian humour is really taking off!" rejoices a man who mistakenly listened to a broadcast of the Estonian Congress instead of the humour broadcast "Amusement". (1)

14. One politician asks another how many countries there are in Estonia [in Estonian the word "maa" (country) is also added to the end of the names of the provinces of Estonia - hence "Mulgimaa" (Mulkland) - translator]. The other responds that Estonia is one country. The first then asks, surprised: "What country is that Mulkland then?" (1)

15. A teacher asks her students the meaning of the colours of the Estonian flag. Kolja announces that white represents the Siberian snow fields where those who talk too much will be sent. (2)

16. At a meeting of ministers the proposal was made to bury the dead: 1 . in plastic bags; 2 . in a vertical position; 3 . above ground from the waist up; 4 . in circles. Thus, in the opinion of different ministers, wood, farm land, stone and iron could be economised. (1)

17. At the kolkhoz, the kolkhozniks are shown a documentary film about Africa. The kolkhozniks: "They walk around naked, evidently they had kolkhozes before we did." (1)

18. The final game of the World Championships in Soccer is between the USA and the USSR. The US coach promises his men a million dollars each if the team wins. The Soviet team wins, since their coach had threatened to send his men to a kolkhoz if they lost. (1)

19. "Do you want me to tell you a joke about cooperatives?" - "Sure, tell me!" - "Give me a ruble/fiver then." (3)

20. It is asked what will help Estonia out of its difficulties. A mainland and island man both respond that work ["work" in Estonian is $t \ddot{o ̈}$, and "you" in Russian is tô - translator] is the solution. A Russian: "You". (1)

21. Snow white meets some little men in the forest. They say that they are the seven dwarves. Snow white: "But there are only three of you?!" - "Layoffs." (18)

\section{b. Conundrums.}

1. Whate states border on the Soviet Union? - Whichever ones want to. (1)

2. A radio announcement in the year 2000: "All's quiet on the Sino-Finnish border!" (2) 
3. What is democracy? - That's when somebody tells you to go to hell, but you instead go wherever you like. (1)

4. What is the Soviet system? Over-talented and lazy.

5. What is the difference between tsarism and socialism? - In tsarist times, power was passed on from father to son, but in socialism from grandfather to grandfather. (1)

6. How do you feel about Soviet power? - The same way I do about my wife: I love her, but am very afraid of her. (1)

7. When were the first Soviet elections? - When God brought Eve before Adam and said to him: "Chose yourself a wife!" (2)

8. Who is white on the inside, red on the outside? - A 1950 counter-revolutionary. (1)

9. What is the ideal politician like? - One who can predict what will happen tomorrow, next week, next month and then is capable of convincingly explaining why things didn't happen that way. (3)

10. What do a hockey player and a politician have in common? - Both know that what they do is unnecessary. (1)

11. What do an American politician and a miniskirt have in common? - They both allow one to see a lot, but not that which is most important. (1)

12. What is the difference between "Pravda" and "Izvestia"? - There is no news in "Pravda" and there is no truth in "Izvestia". (1) [pravda - "truth" in Russian, izvestia - news in Russian translator]

13. Why were there a lot of forest fires in Russia at one time? - The Russians had a slogan: "Let the ground burn under the feet of the drunks!" (1)

14. What do a country's flag and the queen's nightshirt/panties have in common? - Both of them are raised and lowered at the King's behest. (3)

15. What does a person do before rising [here the double meaning of the word to rise/uprise in Estonian is being played on - translator]? - He sleeps. (1)

16. From what was the Estonian republic born? - From a Russian cunt [in Estonian "puts", which sounds like "putsch" (= coup) - translator] and an Estonian cock [in Estonian "asi", which also means "cause" - translator]. (1)

17. What is the largest country in the world? - Estonia. It borders on the Baltic Sea, its capital is Moscow and its best sons are in Siberia. (1)

18. What do the "Ugala" theatre and the Kremlin have in common? - Both are red, the dead are buried beside them and in both of them theatre performances take place. (2)

19. Why was there a hammer and a sickle on the Soviet flag? - They didn't know about the axe yet. (1)

20. What comes after the food program? - The census of the survivors. (3)

21. What is the main meat food after the conclusion of the food program? - A cut-out from the food program. (1)

22. What problem requires for its solution the creation of a group containing the following scholars: a mathematician, a physicist, a biologist, an engineer, a doctor, an architect, an economist, a lawyer and a philosopher? - The potato harvest at the kolkhoz. (1) 
23. What don't centrally planned economies plan the birth of children? - The means of production are in private ownership. (5)

24. What are the three most complicated things in the world? - Japanese machinery, the Chinese language and doing business in Russia. (3)

25. What are the three largest companies in Europe? - Volvo, Salvo and SORVVO. (1) ("Salvo" is a plastics company in Estonia; SORVVO = Estonian acronym for "Department for Combatting Against the Theft of Socialist Property")

26. Why are skis available in Tallinn now? - There's not much snow in Cuba. (8)

27. What is the difference between the ruble and the dollar? - One is backed by tanks and the other by gold. (2)

\section{Living conditions.}

\section{a. Anecdotes.}

1. A sick person asks to see the ear-eye doctor, since he hears one thing, but sees something absolutely different. (1)

2. Russian electronics experts have invented a new type of television which has automatic brushes on the screen, since many Soviet people spit at the screen while watching television. (1)

3. Two friends are arguing in the street. One tries to convince the other that the USSR is far ahead of other states, since in the USSR even bed bugs have lice on their backs. (1)

4. Socialist sclerosis: a pensioner is standing, holding an empty bag, by the door of a store, and asking himself: "Have I already been inside the store or was I just going to go in?" (2)

5. An old lady in the food store asks for rolled ham, Krakow sausage and Doctor sausage. We don't have any of those things, but what a memory you have!" (2)

6. There are two chickens on the counter: one Russian and one foreign. The blue and bony Russian chicken says haughtily: "But I died a natural death!" (1)

7. The stores are empty, since there is nothing to sell. But why are stores so often closed during the day? - For bringing in new supplies. (1)

8. There is no meat in the store. A man asks why the store has a sign which says "Meat". The salesperson: "Well, my shed has "hui" ['cunt' in Russian - translator] written on it, but I actually have firewood in there." (1)

9. A communist, a socialist and a capitalist have arranged a meeting. The socialist is late, because he had to line up to buy sausage. The capitalist: "What is a line?" The communist: "What is sausage?" (3)

10. A woman complains that there is a terrible line outside the bread and milk stores. Her husband gets angry and promises to shoot the minister. Before long there is a great line outside the Kremlin.

11. The Bolsheviks demanded that the word queue [the Estonian word for queue also means "tail" translator] be replaced with the word "line". A little boy: "Mother, the dog is running and his line is following close behind." (1) 
12. A cannon shot. A woman hopes that means that meat has been delivered to the store, but her husband says that important guests have arrived in Moscow. Another shot is heard. The woman: "Didn't the first shot reach its target?" (1) Compare with A IV, a46.

13. In a store, a foreigner asks why there is no black caviar. He is told that there is no demand. The foreigner waits at the counter all day, and really, nobody asked for black caviar. (1)

14. The communists have come to power. They phone one woman and toll her: "Turn your colour television on right away, red caviar is being shown." (1)

15. A worker eats sprat sandwiches every day for lunch. When foreigners come, then the worker eats black caviar sandwiches. - "I spent all night poking the eyes out of those sprats." (1)

16. A man buys candies and discovers that a piece has been bitten off every candy. Back at the store, he is told that there had been a state inspection [usually, state inspection (riiklik vastuvôtt) entailed the stamping of goods, but in this case the inspection apparently went even farther... translator]. (1)

17. A father puts a ration card on a piece of bread and is about to sink his teeth into it. His son is worried that his father might poison himself, because the ration card that he is about to eat is for soap. (1)

18. A flying saucer has apparently been sighted in Russia. - "There's famine there, what else can you do with saucers but throw them out the window." (1)

19. A prisoner asks what food is being offered. He is told that bread and soup are being served. "Can my brother come here from the kolkhoz?" (1)

20. An inventor invented a mousetrap which is made up of a piece of cheese and a piece of sausage, two posts and a razor blade. The invention was not accredited, since we have neither cheese nor sausage. The inventor perfected the invention so that there are now only two posts and a razor. The mouse comes up to it and sees that there is no cheese and no sausage, and cuts his own throat. (3)

21. An Estonian and a Swede are complaining that everything is expensive and that one must pay so much for an apartment. The Swede: "Then life where you come from is just the same as it is in Sweden." (1)

22. Juku is shown his new baby brother. Juku is disappointed: "No teeth, no hair, just like cheap Russian goods!" (1)

23. A boss explains the work week to some young workers: on Monday we rest from the weekend, on Tuesday we prepare for the workdays, Wednesday is a workday, on Thursday we rest after the workday, on Friday we prepare for the weekend, Saturday and Sunday are days of rest. The young: "Go to hell! How long are we gong to have to work our butts off on Wednesday like that..." (1)

24. A foreigner in Russia sees one man digging a hole and another filling it in with dirt right away. The second man explains: "I'm not the second, but the third man. The second man should be here to plant a tree in the hole, but he is sick today." (1)

25. The doorbell rings. The visitor asks for Chapai. Chapai: "He doesn't live here." - "Why did you say that he doesn't live here?" - "Is this life then?" (1) * (Chapai=Chapayev)

26. An insane man's uncle dies in America. At the bank, he is told that his money can be transferred to a Russian bank. The insane man: "I'm not that crazy!" (1)

27. Striptease Soviet style: the dancer takes her clothes off, but instantly gets dressed again, so that the spectators can't steal her clothes. (1) 
28. Three skeletons meet in the street. One died before perestroika, the other died after perestroika, but the third isn't dead yet. (8)

29. A man tells his wife that now that perestroika has arrived, nothing can be had for free anymore. That evening his wife comes to him with a ten-rouble bill in her hand. The man: "Is that for one time in bed?" - "No, three times on the floor and one ruble in change!" (1)

30. A man storms into the cockpit of the Moscow-Leningrad flight and demands that the plane fly to Leningrad. The captain: "This plane has already landed in Sweden three times!" (2) II Ending "Excuse me, I hijacked the wrong plane..." (1)

31. A politician: 'We must eat lots and lots of potatoes, otherwise there won't be enough peels and the Estonian people will die of famine." (1)

32. An English ufology professor argues that an American fighter plane was built by an alien who had been taken prisoner. - "If we could only have an alien help solve the problem of how to get bread delivered to Tallinn stores. (1)

33. "Could you please tell me where you got that toilet paper?" - "From the dry cleaners." (1)

\section{b. Conundrums.}

1. Why does the sun so cheerfully rise in the east? - He knows that by evening he'll already be in the west. (1) Compare with A IV, a23.

2. Is baseball played in Russia? - No, because nobody wants to arrive home. (3)

3. The CIS states' abbreviation at the Albertville olympics was EUN. What does that mean? Eunuchs. (1)

4. What is an antipode [two other words, anti ("was given") and pood (store) are found in the word antipood ("antipode" [sic]) - translator]? - A store in which things were previously sold [here "given" (anti) in Estonian - translator] and no longer are. (1)

5. What is caprice? - A rice with a low nutritional value grown in the capitalist countries. (1)

6. What came first, the chicken or the egg? - Before, there was everything. (1)

7. Why is there no meat? - Pigs are in high places, piglets are members of the party and cows are officers' wives. (1)

8. Where in the Soviet Union is there most bread? - In cotlets. (2)

9. Why was there a drought in the Soviet Union in 1965? - Because people were always singing: "Let the sun always shine!" (24)

10. What is little, green and crisp, but isn't money? - A three-ruble note. (7)

11. Can one survive on one's monthly wages in the Soviet Union? - I don't know, nobody has tried yet. (3)

12. What does this mean - stands, goes, runs? - Everyday life in the former Soviet Union: work is at a standstill, the bottle goes (round) and wages are being paid out ["running" in Estonian translator]. (1)

13. What is piss? - The only thing in Russia which isn't shit. (6)

14. Pitch-patch, not a single flat spot to be seen. What is it? - A repaired Russian asphalt road. (1) 
15. What is a shortage in a shortage? - A smoked sausage wrapped in toilet paper. (2)

16. What is the difference between a bed and a passport? - Under a bed is a pisspot, but under a passport is a podpiss [podpiss is Russian for "signature" - translator]. (1)

17. Is there life on the moon/other planets? - No, there's no life there either. (4)

18. What begins at 9 p.m. and ends at an unknown time? - "Vremja". (2)

19. At what time is most water wasted? - When "Vremja" comes on - some have a bath, some go to the washroom, some wash dishes. (1)

20. Who invented the eletric razor? - Ivan Ivanovitsch Ivanov from the American embassy's trash can. (2)

21. What is 6 tits and a tail? - Leida and a cow. (2) Compare with A IV, a32-33.

22. What is red and shouts "Peace!"? - A tram at "Peace" Tram stop. (3)

23. Do bedbugs glow? - No, because then there would be no need for electricity in Russia. (2)

24. Why did bedbugs move from America/Finland to Russia/Estonia? - Because there is one person for every seven rooms in America, and seven people in one room in Russia. (2)

25. What has a pentagon at the front, dregs inside and stands in front of Tartu train station? - The Pskov train. (1)

26. How can the inhabitants of Estonia be classified? - Estonians, Iestonians and Estontsô [Iestonians are those Slavic inhabitants of Estonia who speak Estonian, albeit with an accent, and Estontsô are those Slavic inhabitants of Estonia who speak no Estonian - translator]. (1)

27. What machine were you thinking of, when you said that Estonia is advancing towards Finland's living standard at mechanised speed? - A road roller. (3)

28. Who sits and thinks up anecdotes? - He who thinks them up sits too [in Estonian istuma ("to sit") also means to be in prison - translator]. (1)

\section{ABBREVATIONS}

ENSV [Estonian abbreviation for Estonian Soviet Socialist Republic - tran slator]: Enne Nälg Siis Viletsus/Viha [First Famine Then Misery/Anger - translator] (23 copies); Eesti NuumSead Venemaale [Estonian Fatted Pigs to Russia - translator] (10 copies)

ETKVL [Estonian abbreviation for Union of Estonian Republican Consumer Cooperatives translator]: Elame Teiste Kulul Väga Lahedasti/Laialt/Lôbusalt [We Live at Others' Expense Very Easily/Luxuriously/Merrily - translator] (89 copies); Eestlased Tagusid Kividega/Kirvestega Venelased Lolliks [Estonians Beat Russians Silly With Stones/Axes - translator] (53 copies); Eesti Talupojad/Targad/Tatid Kolgivad Vene Lolle/Venelasi Luuaga [Estonian Farmers/Smarties/Brats Thrash Russians Fools/Russians with Brooms - translator] (33 copies); Eesti Talupoeg Kinkis Venelasele Leiva/Liha [An Estonian Peasant Gave a Gift of Bread/Meat to a Russian - translator] (23 copies); Eesti Tarkade Klubi Vajab Lolle [The Estonian Smarties' Club Needs Idiots] (18 copies) 
KPSS [Russian abbreviation for Communist Party of the Soviet Union - translator]: Korraldame Peo/Kôva Pidu Sauna ja Seksiga [Let's Organise a Party/A Great Party With a Sauna and Sex translator] (13 copies)

NLKP [Estonian abbreviation for Communist Party of the Soviet Union - translator]: Näljase Lenini Kondine/Kärnane Perse [Starving Lenin's Bony/Scabby Ass - translator] (55 copies)

NSVL [Estonian abbreviation for USSR - translator]: Näljased Silmad/Sead/Sandid Vahivad Läände/Lakke [Starving Eyes/Pigs/Beggars Stare to the West/at the Ceiling - translator] (55 copies)

SSSR [Russian abbreviation for USSR - translator]: Siberi/Suured Sead Situvad/Söövad/Siblivad Reas/Rongis [Big/Siberian Pigs Shit/Eat/Scratch In A Row/In A Train - translator] (219 copies); Stalin/Siga Sôidab/Situb Siberi Rongis [Stalin/A Pig Rides/Shits In A Siberian Train - translator] (38 copies); Stalin Sôitis Seaga Ratsa/Riiga/Rootsi) [Stalin Rode A Pig (also to Riga or Sweden) translator] (44 copies); Stalin/Siga Situb Saba Rôngas [Curly-tailed Stalin/A Curly-tailed Pig Shits translator] (16 copies); Suur Sibula Sööjate Riik [The Big Country of Onion-Eaters - translator] (18 copies)

TASS [The Soviet News Agency]: Targad Ajavad Sitta Suhu [Intelligent People Eat Shit translator] (21 copies)

USA: Uue Sôja Algus [The Beginning of the Next War - translator] (15 copies)

Translated by Alexander Harding

\section{REFERENCES}

Dundes, Alan 1987. Cracking Jokes. Studies of Sick Humor Cycles and Stereotypes. Berkeley.

Kivelä, Marjut 1982. Koululaishuumorin tyyppiluetelu. Helsinki.

Knuuttila, Seppo 1992. Kansanhuumorin mieli. Helsinki.

Sarv, Kadi 1997. "I want to live in the soviet union too!" Childrens' political anecdotes as school tradition. Journal of the Baltic Institute of Folklore. Vol.2, no.1: 73-96.

Virtanen, Leea 1980. Lastenperinne. Helsinki. 